\title{
Bedrock controls on subglacial landform distribution and geomorphological processes: evidence from the Late Devensian Irish Sea Ice Stream
}

\author{
Emrys Phillips*, Jez Everest \& Diego Diaz-Doce \\ British Geological Survey, Murchison House, West Mains Road, Edinburgh EH9 \\ 3LA, Scotland, UK. \\ *corresponding author: e-mail: erp@bgs.ac.uk
}

\begin{abstract}
Ice streams play an important role as regulators of the behaviour of modern ice sheets, taking the form of corridors of fast flowing ice. Similar zones of fast moving ice have also been recognised draining the margins of the Late Devensian British and Irish Ice Sheet. Although the geomorphological and sedimentary signatures of palaeo ice streams have received significant attention, allowing the identification of these former ice streams, the influence of bedrock geology on the processes occurring beneath these palaeo ice streams is less well understood, even though subglacial geology has been shown to control the location ice streams within the West Antarctic Ice Steam. This paper highlights the role played by bedrock geology on landform distribution beneath a much older ice stream, the Late Devensian Irish Sea Ice Stream. The spatial relationships displayed between subglacial landforms and bedrock geology are described from Anglesey, northwest Wales, and the Rhins of Galloway, southwest Scotland; both sites occur close to the eastern margin of this Irish Sea Ice Stream. A link has been established between landform morphology and distribution, and the disposition of the main tectonostratigraphical units within the bedrock. Changes in landform morphology are shown to have been locally controlled by large-scale faults and/or major lithological boundaries, with less durable bedrock lithologies controlling the location and lateral extent of relatively faster flowing portions of the ice stream.
\end{abstract}

\section{Keywords}

Subglacial landforms, landform distribution, bedrock geology, Irish Sea Ice Stream

\section{Introduction}

Ice streams play an important role as regulators in the behaviour of modern ice sheets (e.g. Antarctica, Bamber et al., 2000) and take the form of corridors of fast flowing ice bounded by ice flowing up to an order of magnitude slower (Stokes and Clark, 2001; Bennett, 2003). A number of ice streams have also been recognised draining the margins of the former Late Devensian British and Irish Ice Sheet (Fig. 1a): e.g. eastern Scottish Highlands (Merritt et al., 1995; Golledge and Stoker, 2006); northwest Scotland and the Minch (Bradwell et al., 2007); western Shetland (Davidson and Stoker, 2007); northern England (Everest et al., 2005; Evans et al., 2009); south and northeast Wales (Jansson and Glasser, 2005); northern and central 
Ireland (Knight et al., 1999); and Irish Sea (Ó Cofaigh and Evans, 2001; Scourse and Furze, 2001; Evans and Ó Cofaigh, 2003; Roberts et al., 2007). The geomorphological signature of palaeo ice streams, in particular, has received significant attention (Dyke and Morris, 1988; Hodgson, 1994; Patterson, 1997, 1998; Clark and Stokes, 2001, 2003) allowing the establishment of a set of criteria for identifying the existence/former existence of ice streams (Stokes and Clark, 1999). Work on the sedimentary and structural legacy of ice streams (Clark and Stokes, 2003), although limited, is also increasing. For example, work by Evans and Ó Cofaigh (2003) in southern Ireland, Harris et al., (1997) and Thomas and Chiverrell (2007) in northwest Wales, Williams et al., (2001) in Cumbria, and Thomas et al., (2004) and Roberts et al., (2007) on the Isle of Man, has shown that the sediments at the margin of the Late Devensian Irish Sea Ice Stream were pervasively deformed as it retreated from its maximum extent in the Celtic Sea (Scourse and Furze, 2001). The polyphase deformation histories recorded by these often complex sedimentary successions have been equated with repeated phases of readvance during retreat of a highly dynamic ice sheet margin (Thomas and Chiverrell, 2007). Recently, swath bathymetry data has revealed that subglacial and ice-marginal landform systems associated with the Irish Sea Ice Stream are locally well-preserved offshore of Anglesey, providing evidence for the grounding of the ice sheet during deglaciation (van Landeghem et al., 2008, 2009).

The potential role played by subglacial geology on processes occurring beneath ice streams has been recognised in Antarctica. Anandakrishnan et al. (1998) concluded that the positioning of ice streams in Western Antarctica is dependant upon subglacial geology. The primary objective of this paper is to highlight the role played by bedrock geology on landform distribution beneath a much older ice stream, the Late Devensian Irish Sea Ice Stream. The spatial relationships displayed between subglacial landforms and bedrock geology are described from two sites located close to the eastern margin of this ice stream, Anglesey in northwest Wales and the Rhins of Galloway in southwest Scotland (Fig. 1b). A link between landform morphology and distribution and the disposition of the main tectonostratigraphical units within the bedrock has been established. The locally abrupt changes in the morphology of the landforms developed beneath the Irish Sea Ice Stream have locally been found to have been controlled by large-scale faults and/or major lithological boundaries. The control exerted by less durable bedrock lithologies on location and lateral extent of relatively faster flowing portions of the ice stream are also demonstrated.

\section{Study areas and techniques}

The two study areas, Anglesey (northwest Wales) and the Rhins of Galloway (southwest Scotland), were selected due to: (1) their close proximity to the eastern margin of the Irish Sea Ice Stream (Fig. 1b); (2) they possess a well-preserved suite of subglacial landforms (Thomas and Chiverrell, 2007; Salt and Evans, 2004, respectively); (3) the landforms show very little evidence of being modified during the subsequent retreat of the ice sheet; (4) both areas are relatively low-lying so that the influence on of topography on landform distribution would have been reduced allowing the control exerted by the underlying bedrock to be more clearly assessed; (5) the structure and stratigraphy of the bedrock geology in these areas are wellknown; (6) the structural grain of the bedrock in both areas includes elements that are parallel and orthogonal to the former ice flow direction; and (7) the bedrock geology 
is highly variable, ranging from relatively soft sandstone dominated sedimentary sequences, through to more resistant metamorphic rocks, including, in the case of Anglesey, high-grade gneisses and granitic rocks (see sections 3.2 and 4.2). Although relatively small areas, when compared to the extent of the Irish Sea Ice Stream (see Fig. 1), the variation in bedrock lithology present in both study sites is comparable to that underlying the majority of the northern Irish Sea (see BGS, 1991, 1994; Jackson et al., 1995). Recent geomorphological mapping of a number of areas offshore of Anglesey (Van Landeghem et al., 2008, 2009) has demonstrated that a comparable suite of glacigenic landforms occur beneath the Irish Sea to those present within both study areas. Consequently, Anglesey and the Rhins of Galloway represent ideal terrestrial sites in which to investigate the control of bedrock geology on landform development beneath the Irish Sea Ice Stream.

The key characteristics (orientation, width, length and elongation ratio) of the glacigenic individual landforms present in the two study areas, which includes classical egg-shaped drumlins, were captured and analysed using Arc Map GIS Desktop software package. Using two differently illuminated hill-shaded NEXTMap (C NERC) digital elevation models (see Figs. 6a and 11a) to avoid azimuth bias, the long (length) and short (width) axes of each of the landforms were digitised manually and stored as two separate line datasets. Once digitised, the length and width of the landforms were automatically calculated. The mean, maximum and minimum elongation ratio, length and width of the landforms are listed in Tables 1 and 2, the data displayed graphically on Figs. 2, 3 and 4. Both line data sets (which include the numerical length and width data) were then combined, with the orientation of the individual landforms being represented by a single line (corresponding to its long axis; see Figs. $6 \mathrm{~b}$ and $11 \mathrm{~b}$ ) and attributed with the length and width data for that particular feature. These data were then used to calculate the elongation ratio (long axis (length)/short axis (width)) of the landforms using the Field Calculator. The central point of each landform (i.e. the central point of the long axis), attributed with the elongation ratio value, was then exported to a point dataset allowing the subsequent interpolation of the data into a colour graduated raster format showing the variation in landform elongation ratio across the study area (see Figs. $6 \mathrm{~b}$ and $11 \mathrm{~b}$ ).

A map of the landforms (see Figs. 5a and 10a) and the 1:50,000 digital bedrock geology map (DIGMap) for both Anglesey (see Fig. 8) and the Rhins of Galloway was draped over the NEXTMap hill-shaded digital terrane models for these areas. This allowed a detailed comparison to be made between the distribution and morphology of the landforms and the underlying bedrock geology; in particular, the effect of major changes in bedrock lithology and the presence of large-scale tectonic structures, on the geometry and elongation ratio of the glacigenic landforms. The potential influence of pervasive bedrock structures, such as bedding, cleavage and/or fold axes, on the morphology and orientation of the landforms was also investigated by plotting bedrock structural and landform orientation data on lower hemisphere stereographic projections and rose diagrams (see Figs. 9 and 13).

\section{Example 1: Anglesey, NW Wales}

\subsection{Regional glaciological setting}


It has long been recognised that ice, initially sourced in central and southwest Scotland, flowed south through the southern Irish Sea Basin during the Late Devensian glaciation (Fig. 1) (Tiddeman, 1872; Jehu, 1909; Mitchell, 1960, 1972; Synge, 1964; Bowen, 1973a, b), merging with the Irish Ice Cap to the west and the smaller Welsh Ice Cap to the east, to form the Irish Sea Ice Stream (Merritt and Auton, 2000; Evans and Ó Cofaigh, 2003; Hiemstra et al., 2006; Roberts et al., 2007). Since Tiddeman (1872), most workers have agreed that the advance and retreat of the Irish Sea ice was terrestrial. However, Eyles and McCabe (1989) argued that during the Late Devensian ice expanded down the Irish Sea basin when the floor was isostatically depressed, followed by a marine re-flooding event during deglaciation. These authors believed that this resulted in a rise in relative sea-levels up to $100 \mathrm{~m}$ OD, interpreting most of the outcropping glacigenic sequences below this height as glaciomarine in origin. Subsequent work around the Irish Sea basin (Harris, 1991; McCarroll, 1991, 1995, 2001, 2005; Scourse, 1991a, b; Austin and McCarroll, 1992; McCarroll and Harris, 1992; Harris et al., 1997; Thomas et al., 2004; Merritt and Auton, 2000; Hambrey et al., 2001; Ó Cofaigh and Evans, 2001; Scourse and Furze, 2001; Evans and Ó Cofaigh, 2003; Glasser et al., 2004; Etienne et al., 2006; Thomas and Chiverrell, 2007; Roberts et al., 2007) has rejected this model and the consensus view is that the deposits associated with the Irish Sea Ice Stream, including those on Anglesey, are principally terrestrial in origin.

Anglesey occurs at the eastern margin of the Irish Sea Ice Stream (Fig. 1b), where ice moving southwest met, coalesced with and ultimately decoupled from ice emanating from the Welsh Ice Sheet centred on Snowdonia (McCarroll, 2005; Thomas and Chiverrell, 2007). The glacigenic sequence and landforms on Anglesey are, therefore, key to our understanding of bed conditions beneath the Irish Sea Ice Stream during the Late Devensian.

\subsection{Bedrock geology}

Although a relatively small, topographically low-lying island (c. $735 \mathrm{~km}^{2}$ ), Anglesey displays a very complex bedrock geology. The pre-Quaternary geology of the island can be divided into five main units (Fig. 5b): (i) a pre-Ordovician basement assemblage referred to as the Mona Complex (Greenly, 1919; Gibbons, 1983, 1989; Howells, 2007); (ii) an Ordovician overstep sequence consisting of coarse to finegrained sandstones, conglomerates and mass flow deposits (Bates, 1972, 1974; Beckly, 1987), occupying a Y-shaped tract in central Anglesey; (iii) a volumetrically restricted Silurian succession of deep marine mudstones and volcanic rocks exposed in a small (c. $6 \mathrm{~km} \times 1 \mathrm{~km}$ ), elongate belt centred on Parys Mountain in northern Anglesey; (iv) an unconformable ?Silurian to Devonian fluviatile red-bed succession comprising tabular to trough cross-bedded conglomerates, cross-laminated to planar laminated sandstones and locally calcrete-rich siltstones (Greenly, 1919; Allen, 1965; Davies, 2005); and (v) Carboniferous sedimentary succession which can be divided into an older (Dinantian) shallow marine/lagoonal carbonate sequence comprising bioclastic limestones intercalated with subsidiary terrestrial terrigenous sandstones (Walkden and Davies, 1983; Davies, 1984, 1991; Davies et al., 2004), and a younger (Pennsylvanian), poorly exposed coal-bearing succession of fluviatile to deltaic sandstones and conglomerates (Greenly 1919); the crop of the latter being restricted to the low-lying area beneath Malltraeth Marsh (Fig. 5b). The Siluro-Devonian sequence is exposed in a narrow band on the northwest-side of the Carboniferous succession, 
where it thins rapidly inland from its maximum width at Traeth Dulas on the northeast coast (Fig. 3b).

The Mona Complex has been subdivided into three terranes (Gibbons, 1989) that are separated by low-angle to subvertical, northeast-southwest-trending brittle faults and ductile shear zones. The most prominent of these is the Berw Fault (Fig. 5b) which forms the most westerly strand of the Menai Straits Fault System and is marked by a relatively steep scarp slope. These terranes are thought to represent the disrupted remains of a pre-existing volcanic island arc-subduction complex that were accreted along the northern margin of the Avalonian continent, which was located on the southern side of the Iapetus Ocean, prior to the deposition of the Ordovician overstep sequence. The first terrane, the Monian Supergroup (Shackleton, 1975), crops out extensively across Anglesey (Fig. 3b) and comprises a thick sequence of polydeformed low-grade (greenschist to sub-greenschist facies) metasedimentary rocks (Greenly, 1919; Gibbons, 1983; Phillips, 1991a, b). At the base of this Cambrian (Tietzsch-Tyler and Phillips, 1989; Collins and Buchan, 2004) succession is the Holy Island Group, a sequence (c. $1000 \mathrm{~m}$ thick) of distal to proximal turbiditic metasandstones interbedded with metamudstone and orthoquartzite; the latter includes the Holyhead Quartzite (Phillips, 1991a; Howells, 2007). This is overlain by the schistose metamudstones and metasandstones of the New Harbour Group (c. 2000$3000 \mathrm{~m}$ thick) (Maltman, 1977; Phillips, 1991a, b). The overlying Gwna Group (youngest), is represented by a thick (c. $3000 \mathrm{~m})$ regional-scale olistostromic mélange (Shackleton, 1969, 1975).

The second terrane, the Coedana Complex of central Anglesey (Gibbons, 1989), is a relatively narrow, northeast-southwest-trending belt of poorly exposed Neoproterozoic (Strachan et al., 2007) metasedimentary and metamafic gneisses intruded by the Coedana Granite (Fig. 3b). The southeastern margin of this terrane is formed by a 1.5 to $2 \mathrm{~km}$ wide belt of gently to moderately southeast-dipping schistose rocks referred to as the Central Anglesey Shear Zone (Howells, 2007). The final terrane, the 'blueschist terrane' of southeast Anglesey (Gibbons, 1989; Howells, 2007), is dominated by highly schistose Neoproterozoic metasedimentary rocks that contain disrupted lenses of blueschist facies metabasalts, the famous Anglesey or Monian blueschists (Greenly, 1919; Kawai et al., 2006). Bedding and deformation structures (folds, cleavages) present within the Monian Supergroup, as well as the schistosity within the 'blueschist terrane', are typically oriented northeast-southwest, parallel to the major terrane-bounding faults. In northern Anglesey, however, structures within the Monian Supergroup have been rotated into an east-westorientation by the northerly dipping Carmel Head Thrust (Fig. 3b). This southeastdirected brittle thrust also deforms the overlying Lower Palaeozoic cover sequence (Greenly, 1919; Bates, 1974; Barber and Max, 1979).

\subsection{Landform distribution}

Thomas and Chiverrell (2007) divided the glacigenic sequence on Anglesey into three sediment-landform assemblage zones:

- Zone 1 - an extensive subglacial depositional assemblage, dominated by an extensive drumlin field (Greenly, 1919), covering northern and western Anglesey. The composition of the drumlins varies from being mainly 
composed of Irish Sea Till, through to bedrock dominated features encased in a relatively thin carapace of this till;

- Zone 2 - a subglacial erosional assemblage of northeast-southwest-trending ice-moulded bedrock ridges forming an elongate tract across the central part of the island;

- Zone 3 - an undifferentiated subglacial erosional and depositional assemblage of elongate bedrock ridges, solitary drumlinoid landforms, bedrock channels and proglacial outwash and subglacial (esker) deposits, that covers the remainder of the island. This zone includes the proglacial outwash deposits which occur around Lleiniog (Helm and Roberts, 1984; Hart, 1985) and subglacial esker sediments near Llangefni (Thomas and Chiverrell, 2003).

Analysis of the drumlins and related geomorphological features, using the techniques outlined in section 2, has clearly demonstrated that there are marked differences in the size, elongation ratio (Fig. 2 and Table 1) and orientation (Figs. 5a and 6) of the landforms present in each of the assemblage zones. Consequently, the distribution and extent of the landform assemblage zones on Anglesey, as defined by Thomas and Chiverrell (2007), has been confirmed, with only minor modification to the position of the boundaries of the zones (Figs. 5a and 6).

\subsection{Relationships between landforms and underlying bedrock geology}

Comparison of the NEXTMap digital elevation model (Fig. 6) and landform distribution map (Fig. 5a) with the geological map of Anglesey (Fig. 5b) reveals that the distribution of the sediment-landform assemblage zones corresponds closely with variation in the underlying bedrock. The size, density and distribution of drumlins and other ice sculpted landforms can be seen to change dramatically across major lithostratigraphical boundaries and prominent terrane-bounding faults (Figs. 5a and $6)$.

\subsubsection{Assemblage Zone 1}

Assemblage zone 1 of western Anglesey closely matches the area of outcrop of the Monian Supergroup and the unconformably overlying Ordovician overstep sequence with the landforms being dominated by large equant to smaller moderately elongate drumlinoid landforms (Figs. 2, 5 and 6). The mean, minimum and maximum values of length, width and elongation ratio for landforms developed within assemblage zone 1 are listed in Table 1, with the variation in their elongation ratio shown graphically in Figs. 2 a, 2b and 3a. In detail this assemblage zone can be divided into a number of subzones which reflect lithological changes and/or structures within the bedrock. In northern Anglesey, a large arcuate bedrock ridge (subzone 1a on Fig. 7a), devoid of drumlins, marks the line of the east-west-trending Carmel Head Thrust (see Figs. 5a and 6a), suggesting that this pre-existing tectonic structure influence landform development within the bed of the ice stream. To the southwest of the thrust, in the area around Llyn Alaw (subzone 1b on Fig. 7a), the drumlins reappear and become progressively more elongate in form (Fig. 3a) and exhibit a gentle change in long axis orientation (Fig. 6b) which swings towards the southeast towards Holy Island. Adjacent to the thrust-related bedrock high, an area of more equant (elongation ratios of 1.3 to 1.7; also see Fig. 2a) and slightly larger (Figs. 5a and 6a) landforms corresponds to the Ordovician sequence, as well as the northern part of the Skerries 
Formation of the New Harbour Group (Phillips, 1991a; Howells, 2007) and Gwna Group outcrop (Fig. 8). The strike of bedding and cleavage within the Ordovician sandstones is approximately east-west (Greenly, 1919; Bates, 1974), defining a roughly curving arc which parallels the Carmel Head Thrust. Ice movement direction, defined by the long axis of the landforms, is highly oblique to orthogonal to the strike of these bedrock structures (Figs. 6 and 8). To the south, the long axes of the landforms, and therefore the ice flow direction, occur at a more acute angle to the regional strike of the tectonic fabric (S1) and plunge of the small-scale (F2) folds within the New Harbour Group (Fig. 9).

To the north of the Carmel Head Thrust the drumlins are primarily developed upon the New Harbour Group (subzone 1c on Fig. 7a; also see Figs. 6 and 8) and become progressively more equant in form towards the bedrock high in the hanging wall of the thrust (Fig. 3a). In this area the ice flow direction defined by the landforms occurs oblique to the regional east-west 'structural grain' within the underlying bedrock. The northern coastal strip of Anglesey is apparently devoid of landforms (see Figs. 6a and 8) and glacial sediments, with the New Harbour and Gwna Groups being exposed at the surface. To the north of LLanrhyddlad [SH 333 890] an elongate, roughly north-south-trending area of smaller, more subdued drumlins (subzone $1 \mathrm{~d}$ on Fig. 7a; also see Figs. 6 and 8) clearly cuts across the bedrock ridge formed by the Carmel Head Thrust. This sub-assemblage of smaller, more elongate (elongation ratios of 2.5 to 3.9) landforms has been apparently superimposed upon the larger earlier formed features (Fig. 7a) suggesting that the influence of thrust-related bedrock ridge decreased as glaciation progressed, with this high becoming 'breached'. The site of this 'breach' may have also been bedrock controlled as it coincides with the point at which the quartzose sandstones of the Holy Island Group are cut out against the Carmel Head Thrust (Fig. 8). To the west/northwest subzone 1d is apparently 'curtailed' by a structurally more complex area of folding and faulting within the Ordovician, and thrust imbrication within the Mona Complex resulting from deformation associated with the Carmel Head Thrust.

On Holy Island there is only a very thin, localised, cover of glacial deposits, and constructional landforms are replaced by typically small-scale ice sculpted bedrock features. However, several features are worthy of note. First is the presence of a broad, sloping ice sculpted feature in the vicinity of the village of Rhoscolyn [SH 268 757] at the southern end of the island (RA on Fig. 6). The morphology of this feature mimics the shape of the underlying Rhoscolyn Anticline; a major gentlyinclined, northeast-plunging anticlinal fold which deforms the well-bedded metasandstones of the Holy Island Group. At the northern end of Holy Island the pattern of ice sculpted bedrock features clearly reflects changes in the underlying bedrock, in particular picking out the more resistant Holyhead Quartzite and the prominent northwest-southeast-trending faults which dissect and offset the boundary between the Holy Island and New Harbour groups in this area. Other high relief bedrock features are formed by the relatively more resistant mineralised Silurian volcanic rocks exposed at Parys Mountain [SH 443 905] (PM on Fig. 6) and the large quartzite olistoliths (QZ on Fig. 6) present within a small area of Gwna Group exposed on Mynydd Bodafon [SH 469 850], to the E of Llandyfrydog.

To the northeast of Llyn Traffwll [SH 325 769] and Trefor [SH 375 800] there is an area of distinctive cross-cutting, approximately northeast-southwest and northsouth-trending linear features clearly aligned in a rectilinear pattern on the NEXTMap image (Fig. 7b). The geographical area covered by this rectilinear pattern corresponds remarkably well with the basal conglomerate and sandstone-rich formation of the 
Ordovician overstep sequence (the Treiorwerth Formation of Bates, 1972). Initial structural data obtained for the Ordovician sequence exposed around Llyn Traffwll (Phillips, 1989) indicate that the pattern in the NEXTMap imagery reflects the intersection of moderately to steeply inclined cleavage (60/234, 60/063, 79/234, 81/236, 75/221, 60/241) and more gently dipping bedding (36/360, 42/338, 35/359, 22/018) within the bedrock (Fig. 9d). An area of relatively few landforms occurs in the area to the west of Llanerchymedd [SH 418 841] (Figs. 3a and 6). Bates (1974) showed that the Ordovician succession in this area is structurally complex (see fig. 1 of Bates, 1974) with faulting juxtaposing this folded and cleaved sandstonedominated sequence against the gneissose metamorphic rocks of the Coedana Complex. The northwestern and eastern margins of this area coincide with major faults within the Ordovician bedrock.

\subsubsection{Assemblage Zone 2}

Assemblage zone 2 of central Anglesey closely matches the area of outcrop of the Coedana Complex, Siluro-Devonian and Carboniferous sedimentary successions (Figs. 5 and 6). The more variable bedrock geology is reflected in a more complex assemblage of, in general, larger landforms (Table 1) which range from ice-moulded bedrock ridges to highly streamlined or attenuated landforms (Figs. 5 and 6) that record a slightly convergent northeast-southwest-pattern of ice flow (Fig. 6b) that follows the regional strike of the underlying Precambrian, Lower Palaeozoic and Carboniferous strata (compare Fig. 6b with 5b). The greater complexity of the landforms which characterise assemblage zone 2 is reflected in the more variable pattern of elongation ratio frequency seen on Figs. 2c and d (also see Table 1). The pattern of ice flow within the zone appears to have concentrated into the area now occupied by the alluvial deposits of Malltraeth Marsh (Figs. 5 and 6). The northeastsouthwest-trending eastern boundary to assemblage zone 2 is sharp and corresponds to the subvertical Berw Fault (Fig. 6). A number of smaller scale, strike-parallel faults within the bedrock are picked out by locally deeply incised subglacial meltwater channels in the area between Pentre Berw [SH 523 784] and Treath Coch [SH 535 799] (Fig. 6b), indicating that these bedrock structures partially controlled the pattern of subglacial drainage. Glacial erosion along the line of the Berw Fault has emphasised the fault-scarp present along the southeast-side of the Carboniferous succession; this fault possibly forming the southeast flank of a half-graben into which the coal-bearing Pennsylvanian strata where deposited. These relatively soft strata are deeply incised to form a northeast-southwest-trending trough which extends offshore where it deepens towards the southwest. To the north and northwest of this trough, the attenuated landforms, including the streamlined bedrock features developed upon the more durable Carboniferous limestone-bearing succession (compare Figs. 5 and 6), indicate an apparent funnelling/concentration of ice flow into this trough. The prismatic to rhombic pattern of linear features developed in the area underlain by the Carboniferous limestones reflects the intersection of the subvertical principal joint set (north-south-orientation) and gently southerly dipping bedding (approximately northnortheast-south-southwest-orientation) (Fig. 7c).

In contrast to the southeast-boundary of assemblage zone 2, its western margin is less well defined (see Figs. 5 and 6). In southern central Anglesey this boundary corresponds to the southeastern margin of the Coedana Granite. However, to the northeast, assemblage zone 2 widens and its western margin cuts across the regional trend of the underlying bedrock to intersect the coast at Dulas Bay [SH 480 880] (Figs. 5 and 6). Interestingly, although this boundary does not correspond to a major 
geological boundary in this area, it does mimic the arcuate shape of the outcrop pattern of the Siluro-Devonian redbed succession and Carboniferous limestone dominated strata (exposed some 2 to $3 \mathrm{~km}$ to the east/southeast; compare Figs. 5 and 6 ), and in part corresponds to one of the major rock channels identified by Thomas and Chiverrell (2007). Inland of Traeth Dulas the outcrop of the redbed succession is marked by an area of over deepening to form a prominent, approximately northeastsouthwest-trending channel (cf. Thomas and Chiverrell, 2007), with the geological boundary between the Siluro-Devonian and Carboniferous strata being marked by a distinct ice moulded break of slope (Fig. 6). Near the coast, however, the redbeds form the core to a more resistant bedrock high; the elongate northeast-southwesttrending hill at Capel Elen [SH 485 876]. This elongate ice sculpted feature corresponds to the steeply-inclined to overturned south-facing limb of a large scale fold (the Lligwy Bay Syncline).

\subsubsection{Assemblage Zone 3}

Assemblage zone 3 in eastern Anglesey corresponds to the area of outcrop of the blueschist terrane, the Gwna Group and Carboniferous sedimentary strata, and occurs between the Berw Fault and Menai Straits (Figs. 5 and 6). The more subdued pattern of elongate bedrock ridges and solitary drumlinoid landforms which dominate the zone are largely underlain by the blueschist terrane. The size and elongation ratio of the landforms which characterise zone 3 (see Fig 2 and Table 1) increase progressively from north to south, along the strike of this assemblage zone (Fig. 3b). The orientation of the landforms is parallel to the regional schistosity developed within these metamorphic rocks. In the northeastern part of the assemblage zone, the strike of the underlying bedrock is at a high-angle to the main ice movement direction (see Figs. 5b and 6b). The roughly triangular outcrop pattern of the Ordovician strata in the area to the northwest of Beaumaris [SH 605 760] is marked by an over deepened area bounded to the north and southwest by higher ground of exposed bedrock occupied by the more resistant Carboniferous and Gwna Group strata (see Figs. 5 and 6). In this area, there is a marked decrease in the elongation ratio of the landforms founded upon Gwna Group and Ordovician strata (Fig. 3b).

A distinctive ice scoured bedrock high on the south-side of Treath Coch (Pentraeth Forest [SH 545 790]; Fig. 6) corresponds to an area of bedrock intruded by a relatively high density of northwest-southeast-trending mafic dykes. Contact metamorphism associated with the emplacement of these intrusive igneous rocks would have resulted in the recrystallisation of the adjacent country rocks and, hence, their becoming more resistant than the surrounding strata. In the southwestern part of assemblage zone 3, the marked lithological contrasts between the Carboniferous strata, Gwna Group and blueschist terrane are less apparent in the size and distribution of the landforms; for example between the Carboniferous limestone-dominated sequence and rocks of the blueschist terrane exposed in the area around Brynsiencyn [SH 483 671], to the northeast of Newborough Warren [SH 340 640] (see Figs. 5 and $6)$.

\section{Example 2: Rhins of Galloway, SW Scotland}

\subsection{Regional glaciological setting}


The Rhins of Galloway and adjacent area of southwest Scotland occur close to the onset zone of the Irish Sea Ice Stream (Fig. 1). The Rhins of Galloway form an elongate peninsula that extends south-southwest into the Irish Sea. During the Late Devensian the peninsula was overridden by the main Scottish Ice Sheet as it fed ice moving southward down into the Irish Sea (Late Glacial Maximum). During subsequent deglaciation the area was traversed by a succession of ice streams, until the final disappearance of the ice sheet toward the end of the Late Glacial Period (Charlesworth, 1926; Kerr, 1982; McCabe et al., 1998; Salt and Evans, 2004; Bradwell et al., 2008). Glacial landforms on the Rhins of Galloway and the adjacent area of mainland Scotland are dominated by northeast-southwest-trending drumlins which, along with other streamlined features (Figs. 10 and 11), record ice flow from the northeast (Charlesworth, 1926; Salt and Evans, 2004). This southwest-directed advance accompanied the deposition of a widespread, upper, red to light brown noncalcareous till (Geikie and Geikie, 1869; Kerr, 1982). An older, compact, northderived calcareous till occurs locally and is separated from the upper till by a sand bed; the latter rarely preserving evidence (sand-filled ice cast wedges) for an intervening period of periglacial activity (Kerr, 1982). The southwest-directed advance was followed by a period of ice stagnation and retreat. This was in turn followed by an ice advance towards the south-southeast, passing through Loch Ryan and into the upper part of Luce Bay (Salt, 2001; Salt and Evans, 2004; Peacock and Everest, in press). Charlesworth (1926) identified a belt of 'kame moraines' to the south of Stranraer which he referred to as the Stranraer Moraine, arguing that they resulted from a readvance from the north. Kames, eskers and buried-ice topography often indicate ice decay during active retreat, or may be formed following a surge rather than during normal advance by active ice (Sutherland, 1993; Peacock and Everest, in press), therefore the idea of a northerly readvance has not been entirely rejected (see Salt and Evans, 2004).

\subsection{Bedrock geology}

The bedrock geology of the Southern Uplands is dominated by a series of elongate northeast-southwest-trending fault-bounded tracts of Lower Palaeozoic turbiditic sandstones with interbedded siltstones and mudstones, and rare conglomerates (Stone, 1995; Lintern and Floyd, 2000; Floyd, 2000; Smith et al., 2000). These weakly metamorphosed sedimentary rocks were originally deposited adjacent to the northern margin of the Iapetus Ocean, which separated the continents of Laurentia, to the N, and Gondwana to the south. This major ocean basin finally closed during the late Silurian to early Devonian, resulting in the tilting, southeast-directed thrusting and localised folding of these oceanic sediments (McKerrow et al., 1977; Leggett et al., 1979; Stone et al., 1987). During closure of the ocean the thrusts were progressively back-rotated to form the steeply inclined tract-bounding faults. These faults are locally marked by thin slivers of the condensed, graptolite-bearing deep marine mudstones of the Moffat Shale Group (see Floyd, 2000 and references therein). The Lower Palaeozoic sedimentary rocks are locally unconformably overlain by a younger Carboniferous to Permian sedimentary succession, deposited in a series of elongate, north-south to north-northwest-south-southeast-trending fault controlled basins.

The geology of the Rhins of Galloway is shown in Fig. 10b. In this area the Lower Palaeozoic rocks are divided into two by the Cairngarroch-Orlock Bridge Fault; a major tract-bounding structure that separates the older, Ordovician (Arenig to 
Ashgill) Leadhills Supergroup, to the north, from the younger, Silurian in age, Gala (Llandovery) and Hawick (Late Llandovery to Wenlock) groups to the south. Bedding and cleavage within these rocks are, in general, steeply inclined to vertical with a relatively consistent northeast-southwest-strike, the so called Caledonian trend. The Leadhills Supergroup is subdivided into the locally conglomeratic Corsewall Formation at its base, overlain by a thick, relatively monotonous sequence of wellbedded wacke sandstones belonging to the Kirkcolm, Galdenoch, Portpatrick, Glenwhargen and Shinnel (youngest) formations (Stone, 1995; Floyd, 2000; Smith et al., 2000). The thinner bedded, relatively calcareous sandstones of the Hawick Group crop out on the southern end of the Rhins of Galloway where they are intruded by the dioritic to granitic Portencorkrie complex (Fig. 10b).

On the western side of Loch Ryan the Leadhills Supergroup is unconformably overlain by a very thin (30 m thick) Carboniferous sequence (Fig. 10) of sandstones and interbedded mudstones and seatclays (Leswalt Formation, Stone, 1995). These are in turn unconformably overlain by Permian red sandstones and conglomerates (Loch Ryan Formation, Stone, 1995) that fill a narrow, elongate, northwest-southeasttrending basin which occupied the area between Loch Ryan and Luce Bay, and was bound to the northwest by the Loch Ryan Fault (Fig. 10).

\subsection{Landform distribution}

The general pattern of palaeo ice-stream flow identified by Salt and Evans (2004) is generally confirmed by NEXTMap imagery, however, additional analysis here of the landscape morphology has led to a further development of the interpretation and highlighted the control on former ice flow directions exerted by the bedrock geology. Apart from the meltwater deposits described by Charlesworth (1926), the landforms of the Rhins of Galloway area can be divided into three landform assemblage zones (Figs. 10 and 11) in which the features are constructional, composed of till and/or other glacial deposits:

- Zone 1 - occurs on the Rhins of Galloway and is characterised by generally NE-SW-trending drumlins;

- Zone 2 - occurs between Loch Ryan and the western side of Luce Bay and comprises low, grooved and moulded, south-southeast-trending streamlined landforms, up to $2.5 \mathrm{~km}$ in length, together with low elongate drumlins (e.g. at Knockarod [NW 980650$]$ ). The northwestern part of this zone locally transgresses across drumlinoid/mounded landforms more typical of assemblage zone 1 ;

- Zone 3 - is located to the east of Loch Ryan and Luce Bay, and is dominated by low streamlined forms and drumlins.

Analysis of the geomorphological features clearly demonstrates that there are marked differences in the size, elongation ratio (Fig. 4 and Table 2) and orientation (Figs. 10a and 11) of the landforms present in each of the assemblage zones. There is little evidence for continuous belts of kame moraines recorded by Charlesworth, except for a prominent north-northeast-south-southwest-trending ridge at High Boreland [NX 087 585]. The occurrence of streamlining south of the ridge (e.g. at Knockarod) indicates that much of this ground is underlain either by till or glacially deformed sediment rather than by meltwater deposits. The so-called lateral moraines mapped by 
Charlesworth (1926) to the west of Stranraer are reinterpreted as streamlined landforms.

\subsection{Relationships between landforms and underlying bedrock geology}

Comparison of the NEXTMap digital elevation model with the geological map of the Rhins of Galloway and adjacent area of southwest Scotland reveals that the distribution of the sediment-landform assemblage zones clearly reflects the underlying bedrock (Fig. 10). The size, density and distribution of drumlins and other ice-sculpted landforms can be seen to change dramatically across major lithostratigraphical boundaries and prominent tract-bounding faults (Figs. 10 and 11).

\subsubsection{Assemblage Zones 1 and 3}

Assemblage zones 1 and 3 are underlain by the Lower Palaeozoic bedrock (Fig. 10). The landforms developed within these zones are relatively similar in size and shape (Fig. 4 and Table 2) and are dominated by generally north-northeast-south-southwesttrending drumlins and low streamlined bed forms (Figs. 11 and 12a). In areas of exposed bedrock in zones 1 and 3, the regional trend of bedding and, to a lesser extent, cleavage within the underlying sandstones is picked out by a closely spaced set of northeast-southwest-trending low-amplitude ridges (e.g. in the area to the northeast of Little Cairnbrock [NH 978 667]; Fig. 10). The palaeo ice flow direction defined by the long axes of the drumlins and other streamlined features in zone 1 is typically oblique to the 'structural grain' of the bedrock, occurring at an angle of $30^{\circ}$ to $45^{\circ}$ to the strike of bedding (Fig. 11 and 12b). This indicates that, on a broader scale, ice flow cut across the regional trend of the underlying fault-bound Lower Palaeozoic tracts.

In the northeast of assemblage zone 3, an area of relatively smooth terrain lacking in constructional landforms (Fig. 11) may reflect the former presence of very slow moving ice. This area is centred upon the Kirkcolm Formation (Floyd, 2000; Smith et al., 2000) of the Leadhills Supergroup (see Figs. 10 and 11) and is bound to the north by the Glen App Fault and to the south by the main northerly outcrop of the Galdenoch Formation. To the southwest within assemblage zone 1, however, the along strike lateral equivalent bedrock tract is cross-cut by a set of well-developed north-northeast-south-southwest-trending drumlins. The Glen App Fault forms part of the Southern Upland Fault system which represents a major terrane boundary within the bedrock, separating the Southern Uplands from the Midland Valley terrane immediately to the north. This major fault acted as a focus for glacial erosion and is marked by a prominent northeast-southwest-trending valley (Fig. 11). Similarly, an unnamed NNE-SSW-trending fault, which partially controls the valley of the Water of Luce, has also been exploited by subglacial erosion.

Overall the orientation of the constructional glacigenic landforms in zones 1 and 3 records ice flowing from north-northeast to south-southwest straight across southwest Scotland (Fig. 11b); typical of the earliest phase of ice advance recorded in the area (Kerr, 1982). However, in detail the pattern of ice flow is more complex, reflecting major changes in bedrock geology. In the area on the northeastern side of Luce Bay, to the southeast of Dunragit [NX 152 575], the landforms of zone 3 define a broad curve equated with southerly rotation in ice flow direction from the upland area to the northeast, into the bay (Fig. 11b). Landforms in this area become more elongate in form as they rotate into a more north-south-orientation. These changes in 
ice movement direction and landform morphology broadly correspond to a major change in bedrock geology from the weakly metamorphosed Lower Palaeozoic sandstones in the northeast, to the much softer Permian sandstones occupying the area between Loch Ryan and Luce Bay (see Figs. 10 and 11). The boundary between the Lower Palaeozoic rocks and the younger Permian strata is formed by the Loch Ryan Fault.

Flow lines constructed using the orientation of drumlin and streamlined landform long axes show that the pattern of ice movement in both zones 1 and 3 can be divided into a number of 'domains'. These domains are characterised by localised arcuate to sigmoidal patterns of ice movement (see Fig 12a) recording a deflection of ice movement from a north-northeast-south-southwest-trend to a more northeastsouthwest-orientation parallel to the Caledonian trend of the underlying bedrock (see Figs. 10 and 11). This is most clearly observed within zone 3 in the area around Glenluce [NX 200 576] where the change in orientation of the landforms is spatially related to the tract-bounding Fardingmullach and Glen Fumart faults which form the boundaries between the Portpatrick and Shinnel formations, as Shinnel Formation and Gala Group, respectively (Figs. 11 and 12a). Similar changes in landform orientation are also evident on the Rhins of Galloway within assemblage zone 1 where they occur above the Glen App, Morroch Bay, Drumbreddan and the closely spaced Glaik and Killantringan faults (Fig. 11). The area to the south of the Drumbreddan Fault on the Rhins of Galloway is relatively lacking in glacigenic landforms. This area corresponds to the Hawick Group which is intruded by the Portencorkrie Complex.

\subsubsection{Assemblage Zone 2}

Assemblage zone 2 largely corresponds to the area of outcrop of the Permian sandstones and is characterised by highly elongate streamlined landforms (see Figs. 10 and 11); although the southern part of the zone is largely obscured by later deposits. The northeast margin of the zone is sharp and corresponds to the line of the Loch Ryan Fault. Glacial erosion of this fault line resulted in the formation of a marked topographic feature. The southwestern margin of zone 2 is apparently more gradational in nature. In the area to the south and west of Stranraer the southwest limit of zone 2 corresponds to the unconformity separating the Permian sandstones from the underlying Lower Palaeozoic rocks (Fig. 10a). In the northwest, between Kirkcolm [NX 030 686] and Milleur Point [NX 020 737] the streamlined landforms of zone 2 are superimposed upon a set of earlier northeast-southwest-trending drumlins and are underlain by the Ordovician Corsewall and Kirkcolm formations (see Figs. 10 and 11).

\section{Bedrock controls on landform distribution, subglacial processes and ice flow patterns beneath the Irish Sea Ice Stream}

It is clear from the previous descriptions of the two study areas that the there is a close relationship between the size, distribution and orientation of glacial landforms and the structure and composition of the underlying bedrock. This relationship suggests that bedrock geology can, in some cases, influence the processes occurring near the base of major ice sheets. Patterns of ice-flow have been constructed for both Anglesey and the Rhins of Galloway using the orientation of drumlin and streamlined landforms, and are shown in Figs. $6 \mathrm{~b}$ and $11 \mathrm{~b}$. The results of this study can be used to demonstrate that several key bedrock features including bedrock highs, 'structural 
grain', the presence of large-scale faults, and changes in bedrock durability or hardness can influence processes occurring beneath and patterns of ice flow within ice sheets. The control exerted by these bedrock features on landform distribution and pattern of ice flow beneath the Irish Sea Ice Stream are described below.

\subsection{Bedrock highs}

On Anglesey, the relatively narrow (1.5 to $2 \mathrm{~km}$ wide) bedrock ridge formed above the east-west-trending Carmel Head Thrust had a significant effect on landform distribution within assemblage zone 1 (Figs. 5a, 6 and 7a). This prominent bedrock feature (subzone 1a on Fig. 7a) is devoid of drumlins, possesses a relatively gently northerly dipping up-ice side and steeper down ice expression, and would have presented a focus for subglacial erosion, rather than deposition and associated constructional landform development. Previously published studies have equated bedrock highs with 'sticky spots' within the beds of both ancient and modern glaciers and ice sheets (Licciardi et al., 1998; Kleman and Hattestrand, 1999; Stokes et al., 2007), impeding their forward motion. The ridge-like high formed above the Carmel Head Thrust is likely to have led to a localised deceleration of the Irish Sea Ice Stream as it overrode this 'sticky spot'. The observed systematic changes in the elongation ratio and geometry of the drumlins formed on either side of this bedrock high (Fig. 3a) are interpreted as reflecting this relative slowing down of the ice sheet as it encountered this feature. The change from equant landforms adjacent to the bedrock high (both to the north and south of this feature), to more elongate landforms as the ice flowed southwest across western Anglesey (Fig. 3a), is interpreted as reflecting the initial, relative, deceleration of the ice stream, followed by subsequent acceleration as the Irish Sea Ice Stream overrode this topographic feature. A similar progressive increase in the elongation ratio of the landforms can be observed in southeast Anglesey (Fig. 3b; assemblage zone 3), where the ice was likely to have been accelerating as it crossed the blueschist terrane (Figs. 5 and 6). Small-scale fluctuations in the elongation ratio of the landforms in both assemblage zones 1 and 3 (Figs. 3a and 3b, respectively) are thought to indicate the presence of sticky spots within the bed of the accelerating ice sheet. The poorly exposed nature of the bedrock and glacial sediments in these areas, however, means that the exact nature of the control (either bedrock or till) on the location of these sticky spots is uncertain.

The variation in the geometry of landforms developed on Anglesey indicate that changes in elongation ratio of subglacial landforms can, with care, be used as a proxy for relative changes in velocity of the overriding ice (cf. Stokes and Clark, 2002). The east-west-trending bedrock high in northwestern Anglesey is clearly transverse to the direction of ice flow within the Irish Sea Ice Stream and would have represented a major obstacle within its bed. Maps showing variation in elongation ratio and flow direction (Fig. 6b) can be used to demonstrate that not only did the ice sheet initially decelerate and then subsequently accelerate as it overrode this topographic feature, but was also forced to bifurcate, with part of the flow being diverted around the northeastern end of this high (see Fig. 6b). As noted above, the bedrock high was a focus for subglacial erosion and was eventually 'breached' (Figs. $7 \mathrm{a}$ and 8), recording the initial stages of its removal. Consequently, any control exerted by bedrock features on ice sheet dynamics may potentially, with time, diminish due to either their removal by either subglacial erosion and/or burial beneath a thick pile of subglacial sediments. The combined effect of subglacial erosion and 
deposition is to smooth out any perturbations in the bed of the ice sheet. However, in parts of Anglesey and the Rhins of Galloway the superficial cover is relatively thin or patchily developed, potentially enabling a bedrock control on subglacial processes during the entire existence of the Irish Sea Stream.

\subsection{Bedrock 'structural grain' and bedrock 'stickiness'}

In both study areas the lower ratio landforms, and by inference the slower moving ice, occur where the ice stream was flowing over the polydeformed and metamorphosed metasedimentary rocks (Anglesey, assemblage zone 1 - Monian Supergroup and overlying Ordovician strata; Rhins of Galloway, assemblage zones 1 and 3 Ordovician and Silurian strata, Figs. 3, 6 and 11). Along the north coast of Anglesey and on the bedrock high formed above the Carmel Head Thrust, bedding and/or schistosity within the exposed bedrock is marked a clear pattern of small-scale, eastwest-trending ridges (see Fig. 8). Similar features occur on the Rhins of Galloway where a set of parallel, low-amplitude, closely spaced ridges reflect the well-bedded nature of the underlying Lower Palaeozoic metasandstones (Fig. 12b). In the absence of a thick subglacial sedimentary sequence in these areas, the laterally extensive ridge-like features would have represented a persistent irregularity within the glacier bed, effectively increasing its 'roughness' and therefore 'stickiness'. Consequently, in areas of thin or patchily developed subglacial sediment cover the structural grain of the bedrock can influence the relative velocity of the overriding ice.

Evidence from both Anglesey and the Rhins of Galloway, however, suggests that the degree of angular discordance between the strike of a pervasive bedrock structure (e.g. bedding, schistosity, cleavage) and the principal ice flow direction may affect its relative "stickiness" and that of any bedrock highs (the greater the angle = the greater the roughness of the bed = the 'stickier' the high). In northern Anglesey (assemblage zone 1) the strike of both bedding and schistosity present within the Monian Supergroup are orthogonal to the principal ice flow direction. To the southwest, more elongate landforms occur where ice flow was oblique (c. $30^{\circ}$ to $40^{\circ}$ ) to the strike of the foliation within the New Harbour Group (Figs. 9a to c). A similar oblique relationship between ice flow direction and the 'structural grain' of the bedrock also occurs within assemblage zones 1 and 3 of the Rhins of Galloway (Fig. 13). In this situation the potential for small-scale bedrock ridges to impede ice flow would be reduced; essentially the smaller the angle between ice flow direction and the 'structural grain' of the bedrock, the lower its effect on bed roughness. This is supported by the relationships present within assemblage zones 2 and 3 on Anglesey the regional strike of the steeply inclined schistosity and main ice flow direction are coincident, as a result the bedrock features are streamlined and less of a hindrance to the smooth passage of the overriding ice.

The angle of dip of these bedrock structures may influence the geomorphological characteristics of any high formed within the bed of the ice sheet. For example, sub-horizontal bedding may lead to step-sided bedrock highs, whereas in areas of subvertical bedding where the regional strike and ice flow direction are coincident would preferentially lead to the formation of steep-sided elongate ice-

sculpted features. One important point to be made here is that where ice flow direction and structural trend of the bedrock are coincident, care must be taken when attempting to use highly elongate ice-sculpted bedrock features as the sole proxy for establishing the relative speed of the overriding ice. In areas where sub-vertically 
dipping beds or layers of resistant rock, such as basalt, occur within a softer host lithology and are aligned parallel to the ice movement direction, these harder units may preferentially lead to the formation of highly elongate landforms irrespective of the relative velocity of the overriding ice.

\subsection{Localised deflection of ice flow in response to large-scale faults}

On the Rhins of Galloway, Salt and Evans (2004) interpreted localised changes in the landform orientation within their Glenluce and Rhins districts as recording a complex set of separate, superimposed phases of ice advance (also see fig. 3 of Evans et al., 2009). However, the small-scale changes in landform orientation (assemblage zones 1 and 3, this study) are systematic and can be directly related to the presence of the northeast-southwest-trending, tract-bounding faults within the bedrock, in particular the Fardingmullach, Glen Fumart, Glen App, Morroch Bay, Drumbreddan and closely spaced Glaik and Killantringan faults (Figs. 11 and 12a). The result was the segmentation of the pattern of ice movement between the faults into a series of arcuate or sigmoidal flow trajectories (Fig. 12a) during a single southwest-directed phase of ice advance. The recognition that prominent bedrock structures can locally affect the pattern of ice movement has led to a simplification of at least part of the glacial history of the Rhins of Galloway. The dextral pattern of off-set present in the ice flow trajectories (see Fig. 12a) occurred as ice advancing from the northeast was deflected in the vicinity of the steeply inclined faults which strike at a moderate to high angle to the principal direction of ice flow. In general, the faults are not marked by any obvious topographic surface expression, suggesting that their influence was more likely to have been on subglacial processes. The faults are marked by highly deformed lenses of mudstone (Moffat Shales) and locally wide zones of brittle deformation leading to an increase in the porosity/permeability within the bedrock. It is likely that such localised changes in bedrock permeability would have also influenced the hydrodynamic system set up within the bed of the overlying ice sheet, which in turn may have affected ice movement.

\subsection{Bedrock durability or hardness}

The durability or hardness of the bedrock on both Anglesey and the Rhins of Galloway played a role in controlling the relative velocity or sitting of faster flowing zones the overriding ice stream. On Anglesey the coal-bearing Carboniferous and sandstone dominated Siluro-Devonian strata, which underlie the highly elongate landforms of assemblage zone 2 (see Figs. 5a and 6), were deeply incised by subglacial erosion to form a northeast-southwest-trending trough, informally referred to as the Malltraeth trough (Fig. 5), which deepens towards the southwest. To the north and northwest of this trough, the change in orientation of landforms, which include the streamlined bedrock features developed upon the more durable Carboniferous limestone-bearing succession (Figs. 6 and 7c), records the funnelling and relative acceleration of the overriding ice as it was drawn down into the Malltraeth trough. The relationship between this over deepened trough and the underlying bedrock geology is shown in Fig. 14. The progressive erosion of the softer sedimentary rocks within the Malltraeth trough would have facilitated the build up of a relatively thick, but localised, subglacial sequence beneath this part of the ice sheet. 
Over time, this would have resulted in a localised change in the dominant mechanism responsible for forward motion of the ice sheet, possibly from one dominated by basal sliding and/or ice deformation associated with a very thin sediment bed or ice-bedrock contact, to one in which movement was dominated by deformation of a thicker soft bed. Fault-guided subglacial meltwater channels in the area between Pentre Berw [SH 470 725] and Treath Coch [SH 530 800] (Figs. 6 and 14) would have helped feed pressurised water into the Malltraeth trough, facilitating bed deformation, and leading to increased forward motion of the ice sheet. The combination of potentially high pore-water contents/pressures and the sand-rich nature of the sediment derived from the sandstone-rich bedrock sequences, would/could have aided dilation of the deforming bed during the introduction of subglacial meltwater, thereby reducing basal friction and leading to a relative speeding up of the overriding ice.

The southeast-margin of the Malltraeth trough is confined by the steeply inclined Berw Fault and the much harder, subvertical, schistose rocks of the 'blueschist terrane' (Fig. 14). Consequently, expansion in the area of drawdown feeding this zone of accelerating ice flow, at least initially, appears to have been largely accommodated by ice resting on the more gently inclined rocks of the Gwna Group and Central Anglesey Shear Zone located to the northwest (Fig. 14). The 'structural grain' of these metamorphosed basement rocks is coincident with the principal ice flow direction and, therefore, would not have necessarily impeded the propagation of the zone of faster flowing ice across these rocks. As the area of drawdown expanded towards the northeast it would have encountered the limestonedominated Carboniferous succession (Figs. 6 and 14); a relatively free-draining sequence that is essentially devoid of a glacigenic cover. Although the ice-sculpted landforms developed upon the Carboniferous limestones have a high elongation ratio, these rocks may have represented a 'sticky spot' within the floor of the zone of relatively faster flowing ice, forcing a further widening of the area of drawn down and observed expansion of assemblage zone 2 in this area (see Fig. 6).

A similar model involving the relative acceleration of the ice sheet as it overrode softer bedrock is supported by the close spatial relationship between assemblage zone 2 and the Permian sandstone on the Rhins of Galloway. The margins of the zone are controlled to the northeast by the Loch Ryan Fault and to the southwest, by the basal Carboniferous/Permian unconformity (see Figs. 10 and 11). Landforms on the southwestern side of the zone exhibit a rapid decrease in elongation ratio towards the higher ground formed by the Lower Palaeozoic rocks (Figs. 11 and 12b); indicative of a potential frictional drag effect caused by either a rise in topography and/or change in bedrock lithology. A link between frictional drag on the overriding ice and bedrock geology is supported by the decrease in the elongation ratio of the landforms at the northwestern end of zone 2 where the bedrock is composed of the Corsewall and Kirkcolm formations (Fig. 10). Immediately to the southeast, the elongation ratio of the landforms rapidly increases as the ice passes onto the softer Carboniferous and overlying Permian strata (Fig. 12b). Closely spaced, resistant beds of Palaeozoic metasandstone form a series of low amplitude ridges, transverse to the southeast-directed ice movement direction responsible for the streamlined landforms of zone 2. As noted above, such ridges would increase the 'roughness'/'stickiness' of the bed, leading to the deceleration of the overriding ice sheet.

The influence of the Loch Ryan Fault, which forms the northeast margin of the postulated zone of 'faster flowing' ice, seems to vary along its length from north to south. In the north, the steeply inclined fault denotes a sharp boundary between 
assemblage zones 2 and 3, with the area to the east of the fault apparently being devoid of any obvious landforms (Fig. 11) and representing an area over either static or very slow moving ice. To the south/southwest, the strike of the Loch Ryan Fault changes orientation from north-northeast-south-southwest to approximately northwest-southeast (Figs. 10 and 11). In this area, adjacent to the northeastern side of Luce Bay, the elongation ratio of the landforms developed within the southern part of assemblage zone 3 increases rapidly southwards, accompanied by a swing in orientation towards a more north-south-trend (Figs. 11 and 12a). This is consistent with the ice sitting over the southern part of assemblage zone 3 occurring within an area of draw down which fed the relatively faster flowing ice occupying the broad trough-like feature represented by Loch Ryan and Luce Bay. If this interpretation is correct it would mean that the landforms in the southern part of assemblage zone 3 are 'polycyclic' and formed in response to at least two major phases of ice movement. In contrast to the eastern side of Luce Bay, there is very little if any evidence for the draw down of ice sitting over the Rhins of Galloway.

\subsection{Potential bedrock control on landform distribution beneath the Irish Sea Ice Stream}

Recent work by van Landeghem et al. (2008, 2009), using swath bathymetry, has commenced the mapping of the glacial and post-glacial landforms present on the bed of the Irish Sea. This work has revealed the presence of well-preserved subglacial and ice-marginal landforms (including drumlins, flutes, ribbed moraines and eskers) some 20 to $25 \mathrm{~km}$ offshore of northern Anglesey. Van Landeghem et al. $(2008,2009)$ interpreted the landforms as providing evidence for the grounding of the Irish Sea Ice Stream during deglaciation. The size and variation in the distribution of the landforms mapped by van Landeghem et al., (2009) are comparable to those seen on the Rhins of Galloway and Anglesey. Importantly, in their area 1, van Landeghem et al. (2009) noted that the ribbed moraines, which are very well-developed over the majority of this area of the seabed, were absent immediately above the hinge of a major NEtrending anticline (the Quadrant 109 Arch of Jackson et al., 1995) developed within the underlying Carboniferous bedrock (see fig. 3 of van Landeghem et al., 2009). The subcrop of the Carboniferous bedrock is close to the seabed with only a thin Quaternary cover over the hinge of the anticline, with the trend of this major fold occurring parallel to the main ice flow direction.

Area 2 of van Landeghem et al. (2009), located at the notheastern end of a large northeast-southwest-trending trough within the seabed (see fig. 6 of Landeghem et al., 2009). In this area the glacially streamlined landforms (flutes) and drumlins are interpreted by Landeghem et al. (2009) as recording convergent ice-flow as ice flowed southeast into the central Irish Sea Basin, along the edge of an exposed rock platform. The trough is founded upon Carboniferous (Namurian) bedrock which, onshore, comprises a sequence of mudstones and siltstones with thick sandstone units. The southern margin of the trough is composed of more resistant Carboniferous (Dinantian) limestones which form a narrow strip along the northwestern margin of the Holy Island Shelf (Jackson et al., 1995); the latter comprising a sequence of metamorphosed Lower Palaeozoic and basement (Mona Complex-like) rocks. The convergence of ice flowing into the offshore trough founded upon less resistant Carboniferous strata is comparable to the situation within assemblage zone 2 on Anglesey where converging ice flow is being drawn down into the Malltraeth trough. 
The less resistant Carboniferous sandstones and mudstones in both situations facilitate potentially penecontemporaneous over-deepening by glacial erosion. A similar effect of ice being drawn down into a subglacial trough, leading to a pattern of convergent ice flow, has also been recognised in assemblage zone 2 on the Rhins of Galloway were the trough (now occupied by Luce Bay) is carved into relatively softer Permian strata (see Fig. 12).

The geomorphological mapping of the Irish Sea basin has only just begun (van Landeghem et al., 2008, 2009). However, the comparison between the results of the present study on Anglesey and the Rhins of Galloway with those of van Landeghem et al. (2009) indicate that major structures and lithological changes within the bedrock appear to have locally controlled subglacial landform distribution and the positioning of relatively faster flowing zones across the bed of the Irish Sea Ice Stream.

\section{Conclusions}

Several conclusions can be drawn regarding the distribution and extent of the landform assemblage zones identified on Anglesey and the Rhins of Galloway reflecting potential bedrock controls on processes occurring beneath the eastern margin of the Late Devensian Irish Sea Ice Steam:

- Changes in the geometry, density and distribution of drumlins and other ice sculpted landforms can be directly related to major changes in bedrock geology. Sharp, well-defined boundaries between the landform assemblage zones on both Anglesey and the Rhins of Galloway correspond to major lithostratigraphical boundaries (e.g. base Permian unconformity on the Rhins of Galloway) and/or prominent faults (e.g. Berw Fault on Anglesey);

- As recognised by previous studies on both ancient and modern glaciers and ice sheets, bedrock highs within their beds represent 'sticky spots' impeding forward motion. The east-west-trending, bedrock ridge developed above the Carmel Head Thrust on Anglesey had a significant effect on landform distribution within the bed of the Irish Sea Ice Stream and presented a focus for subglacial erosion, rather than deposition and associated constructional landform development;

- The variation in the geometry of drumlins developed on either side of a major bedrock high in western Anglesey indicates that changes in elongation ratio of these subglacial landforms can be used as a proxy for relative changes in ice flow velocity. It is possible that maps showing the variation in elongation ratio and ice flow direction may be used to show potential changes in the ice flow velocity and trajectory across the bed of an ice sheet;

- The presence of pervasive bedrock structures such as bedding and/or cleavage can lead to an increase in bed roughness and, therefore, a decrease in the velocity of the overriding ice. The most streamlined bedforms occur in areas where ice-flow direction coincides with the regional strike of the bedrock structure. Consequently, the angle between the ice movement direction and the 'structural grain' of the bedrock represents a key factor in determining the 
degree to which bedrock structure will influence the relative velocity of the overriding ice;

- Evidence from the Rhins of Galloway indicates that the presence of largescale faults within the bedrock may result in localised changes in the pattern of ice movement. Such faults are often marked by wide zones of brittle deformation leading to an increase in bedrock permeability, which in turn may have influenced the subglacial conditions beneath the overlying ice sheet;

- Bedrock lithology can play an important role in controlling the relative velocity and/or location of faster flowing zones the overriding ice stream. The less durable (softer) sandstone-dominated successions on both Anglesey (Carboniferous) and Rhins of Galloway (Permian) were deeply eroded in response to subglacial erosion, leading to the formation of elongate bedrock troughs. These troughs acted as a focus for ice movement, drawing down more slowly moving ice into the developing zones of relatively faster flowing ice. The progressive erosion of softer sedimentary rocks may facilitate the deposition of a thick subglacial sequence beneath at least part of the ice sheet, resulting in localised changes in the dominant mechanism responsible for forward motion of the ice sheet.

- Comparison of the results from this study, with the distribution of landforms within the Irish Sea of offshore of northern Anglesey (van Landeghem et al. 2008, 2009) indicate that major structures and lithological changes within the bedrock may potentially have controlled subglacial landform distribution and siting of relatively faster flowing zones across the entire bed of the Irish Sea Ice Stream.

\section{Acknowledgements}

This work forms part of the British Geological Survey's Geology and Landscape Wales Programme. Dave Schofield, Jerry Davies and Tom Bradwell are acknowledged for helpful discussions and comments on an earlier version of this paper. Neil Glasser and one anonymous reviewer, as well as the guest editor Jasper Knight, are thanked for their constructive reviews. This paper is published with the permission of the Executive Director, British Geological Survey (National Environmental Research Council).

\section{References}

Allen, J.R.L., 1965. The sedimentation and palaeogeography of the Old Red Sandstone of Anglesey, North Wales. Proceedings of the Yorkshire Geological Society 35, 139-185. 
Anandakrishnan, S., Blankenship, D.D., Alley, R.B., Stoffa, P.L., 1998. Influence of subglacial geology on the position of a West Antarctic ice stream from seismic observations. Nature 394, 62-65.

Austin, W.E.N., McCarroll, D., 1992. Foraminifera from Irish Sea glacigenic deposits of Abedaron, western Llyn, North Wales: palaeoenvironmental implications. Journal of Quaternary Science 7, 311-317.

Bamber, J.L., Baldwin, D.J., Gogineni, S.P., 2003. A new bed elevation data set for modelling the Greenland ice sheet. Annals of Glaciology 37, 351-356.

Barber, A.J., Max, M.D., 1979. A new look at the Mona Complex (Anglesey, North Wales). Journal of the Geological Society of London 136, 407-432.

Bates, D.E.B., 1972. The stratigraphy of the Ordovician rocks of Anglesey. Geological Journal 8, 29-58.

Bates, D.E.B., 1974. The structure of the Lower Palaeozoic rocks of Anglesey, with special reference to faulting. Geological Journal 9, 39-60.

Beckly, A.J., 1987. Basin development in North Wales during the Arenig. Geological Journal 22, 19-30.

Bennett, M.R., 2003. Ice streams as the arteries of an ice sheet: their mechanics, stability and significance. Earth Science Reviews 61, 309-339.

Bos, J.A.A., Dickson, J.H., Coope, G.R., Jardine, W.G., 2004. Flora, fauna and climate of Scotland during the Weichselian Middle Pleniglacial- palynological, macrofossil and coleopteran investigations. Palaeogeography, Palaeoclimatology \& Palaeoecology 204, 65-100.

Bowen, D.Q., 1973a. The Pleistocene history of Wales and the borderland. Geological Journal 8, 207-224.

Bowen, D.Q., 1973b. The Pleistocene succession of the Irish Sea. Proceedings of the Geologists’ Association 84, 249-272.

Bradwell, T., Stoker, M., Golledge, N., Wilson, C., Merritt, J., Long, D., Everest, J., Hestvik, O., Stevenson, A., Hubbard, A., Finlayson, A., Mathers, H., 2007. The northern sector of the last British Ice Sheet: maximum extent and demise. Earth Science Reviews 88, 207-226.

Brady, G.S., Crosskey, H.W., Robertson, D., 1874. The Post-Tertiary Entoma castraca of Scotland. Palaeontographical Society Monograph, London 1-229.

British Geological Survey, 1991. Geology of the United Kingdom and the adjacent continental shelf. 1:1000, 000 scale. British Geological Survey, NERC.

British Geological Survey, 1994. East Irish Sea (Special Sheet Edition). 1:250 000. Edinburgh Scotland: British Geological Survey. 
Charlesworth, J.K., 1926. The readvance, marginal kame moraine of the south of Scotland, and some later stages of retreat. Transactions of the Royal Society of Edinburgh 55, 25-50.

Clark, C.D., Stokes, C.R., 2001. Extent and basal characteristics of the M'Clintock Channel Ice Stream. Quaternary International 86, 81-101.

Clark, C.D., Stokes, C.R., 2003. Palaeo-ice stream systems. In Evans, D.J.A. (ed.) Glacial Landsystems. Arnold, London 204-227.

Collins, A., Buchan, C., 2004. Provenance and age constraints of the South Stack Group, Anglesey, UK: U-Pb SIMS detrital zircon data. Journal of the Geological Society of London 161, 743-746.

Davies, J.R., 1984. Sedimentary cyclicity in late Asbian and early Brigantian (Dinantian) limestones of the Anglesey and Llandudno districts, North Wales. Proceedings of the Geologists Association 95, 392-393.

Davies, J.R., 1991. Karstification and pedogenesis on a late Dinantian carbonate platform, Anglesey, North Wales. Proceedings of the Yorkshire Geological Society 48, 297-321.

Davies, J.R., 2005. Porth-y-mor, Anglesey. In Barclay, W.J., Browne, M.A.E., Macmillan, A.A., Pickett, E.A., Stone, P., Wilby, P.R., (eds.) The Old Red Sandstone of Great Britain. Joint Nature Conservation Committee, Peterborough 221-228.

Davies, J.R., Wilson, D., Williamson, I.T., 2004. Geology of the country around Flint: memoir for 1:50 000 geological sheet 108 (England and Wales). British Geological Survey (England and Wales), Nottingham: British Geological Survey.

Davidson, S., Stoker, M.S., 2007. Ice streams and Ice Sheets Limits from the West Shetland Margin: The offshore view of the last British Ice Sheet in North-West Britain. Abstracts of Papers, Quaternary Research Association, Annual Discussion Meeting, St. Andrews. 20.

Dyke, A.S., Morris, T.F., 1988. Drumlin fields, dispersal trains, and ice streams in Arctic Canada. Canadian Geographer 32, 86-90.

Etienne, J.L., Jansson, K.N., Glasser, N.F., Hambrey, M.J., Davies, J.R., Waters, R.A., Maltman, A.J., Wilby, P.R., 2006. Palaeoenvironmental interpretation of an icecontact glacial lake succession: an example from the late Devensian. Quaternary Science Reviews 25, 739-762.

Evans, D.J.A., Ó Cofaigh, C., 2003. Depositional evidence for marginal oscillations of the Irish Sea ice stream in southeast Ireland during the last glaciation. Boreas 32, 76-101. 
Evans, D.J., Livingstone, S.J., Vieli, A., Ó Cofaigh, C., 2009. The palaeogeography of the central sector of the British and Irish Ice Sheet: reconciling glacial geomorphology and preliminary ice sheet modelling. Quaternary Science Reviews 28, 740-758.

Everest, J.D., Bradwell, T., Golledge, N.R., 2005. Subglacial landforms of the Tweed Palaeo-Ice stream. Scottish Geographical Journal 12, 163-173.

Everest, J.D., Peacock, D. in press. Short Communication: Pre-late Devensian highArctic marine deposits in SW Scotland. Scottish Journal of Geology 46.

Eyles, N., McCabe, A.M., 1989. The Late Devensian (<22,000 BP) Irish Sea Basin: the sedimentary record of a collapsed ice sheet margin. Quaternary Science Reviews 8, 307-351.

Floyd, J.D., 2000. The Southern Uplands terrane: a stratigraphical review. Transactions of the Royal Society of Edinburgh: Earth Sciences 91, 349-362.

Geikie, A., Geikie, J., 1869. Ayrshire: Southwestern District. Memoir of the Geological Survey: Scotland. Explanation of Sheet 7. Murray and Gibb, Edinburgh.

Gibbons, W., 1983. Stratigraphy, subduction and strike-slip faulting in the Mona Complex of north Wales: a review. Proceedings of the Geologists Association 94, 147-163.

Gibbons, W., 1989. Suspect terrane definition in Anglesey, North Wales. In Dallmeyer, R.D. (ed.) Terranes in the Circum-Atlantic Palaeozoic orogens. Geological Society of America, Special Paper 230, 59-66.

Greenly, E., 1919. The geology of Anglesey. Memoir (District) Geological Survey of Great Britain. HMSO, London 980.

Glasser, N.F., Etienne, J.L., Hambrey, M.J., Davis, J.R., Waters, R.A., Wilby, P.R., 2004. Glacial meltwater erosion and sedimentation as evidence for multiple glaciations in west Wales. Boreas 33, 224-237.

Golledge, N.R., Stoker, M., 2006. A palaeo-ice stream of the British Ice Sheet in eastern Scotland. Boreas 35, 231-243.

Harris, C., 1991. Glacial deposits at Wylfa Head, Anglesey, North Wales: evidence for Late Devensian deposition in a non-marine environment. Journal of Quaternary Science 6, 67-77.

Harris, C., Williams, G., Brabham, P. Eaton, G., McCarroll, D., 1997. Glacitectonized Quaternary sediments at Dinas Dinlle, Arvon, North Wales and their bearing on the style of deglaciation in the eastern Irish Sea. Quaternary Science Reviews 16, 109127.

Hart, J.K., 1990. A reinterpretation of the sequence at Dinas Dinlle. In Addison, K., Edge, M.J., Watkins, R., North Wales Field Guide. Quaternary Research Association (Great Britain) 63-70. 
Hart, J.K., 1995. Drumlin formation in southern Anglesey and Arvon, northwest Wales. Journal of Quaternary Science 10, 2-14.

Hambrey, M.J., Davies, J.R., Glasser, N.F., Waters, R.A., Dowdeswell, J.A., Wilby, P., Wilson, D., Etienne, J.L., 2001. Devensian glacigenic sedimentation and landscape evolution in the Cardigan area of southwest Wales. Journal of Quaternary Science 16, 455-479.

Helm, D.G., Roberts, B., 1984. The origin of late Devensian sands and gravels, southeast Anglesey, N. Wales. Geological Journal 19, 33-55.

Hiemstra, J.F., Evans, D.J.A., Scourse, J.D., McCarroll, D., Furze, M.F.A., Rhodes, E., 2006. New evidence for a grounded Irish Sea glaciation of the Isles of Scilly, UK. Quaternary Science Reviews 25, 299-309.

Hodgson, D.A., 1994. Episodic ice streams and ice shelves during retreat of the northwestern most sector of the Late Wisconsinan Laurentide Ice Sheet over the central Canadian Arctic archipelago. Boreas 23, 14-28.

Howells, M.F., 2007. British Regional Geology: Wales. British Geological Survey.

Irvine, D.R., Geikie, A., 1872. Wigtownshire - Mull of Galloway. Memoir of the Geological Survey: Scotland. Explanation of Sheet 1. Murray and Gibb, Edinburgh.

Irvine, D.R., Geikie, A., 1873. Western Wigtownshire. Memoir of the Geological Survey: Scotland. Explanation of Sheet 3. Murray and Gibb, Edinburgh.

Jackson, D.I., Jackson, A.A., Evans, D., Wingfield, R.T.R., Barnes, R.P., Arthur, M.J., 1995. The geology of the Irish Sea. United Kingdom Offshore Regional Report 20-24. HMSO for the British Geological Survey, London.

Jansson, K.N., Glasser, N.F., 2005. Palaeoglaciology of the Welsh sector of the British-Irish Ice Sheet. Journal of the Geological Society of London 162, 25-37.

Jehu, T.J., 1909. The glacial deposits of western Caernarvonshire. Transactions of the Royal Society of Edinburgh 47, 17-56.

Kawai, T., Windley, B. F., Terabayashi, M., Yamamoto, H., Maruyama, S., Isozaki, Y., 2006. Mineral isograds and metamorphic zones of the Anglesey blueschist belt, UK: implications for the metamorphic development of a Neoproterozoic subductionaccretion complex. Journal of Metamorphic Geology 24, 591-602.

Kerr, W.B., 1982. Pleistocene ice movements in the Rhins of Galloway. Transactions of the Dumfries and Galloway Natural History Society, 3rd Series 55, 25-50.

Kleman, J., Hattestrand, C., 1999. Frozen-bed Fennoscandian and Laurentide ice sheets during the Late Glacial Maximum. Nature 402, 63-66. 
Knight, J., McCarron, S.G., McCabe, A.M., 1999. Landform modification by palaeoice streams in east-central Ireland. Annals of Glaciology 28, 161-167.

Leggett, J.K., McKerrow, W.S., Eales, M. 1979. The Southern Uplands of Scotland; a Lower Palaeozoic accretionary prism. Journal of the Geological Society of London 136, 755-70.

Licciardi, J.M., Clark, P.U., Jenson, J.W., MacAyeal, D.R., 1998. Deglaciation of a soft-bedded Laurentide Ice Sheet. Quaternary Science Reviews 17, 427-448.

Lintern, B.C., Floyd, J.D., 2000. Geology of the Kirkcudbright-Dalbeattie district. Memoir of the British Geological Survey, Sheets 5W, 5E and part of 6W, Scotland. British Geological Survey, Keyworth, Nottingham.

Maltman, A.J., 1977. The Serpentinites and related rocks of Anglesey. Geological Journal 12, 113-128.

McCabe, M. Knight, J., McCarron, S., 1998. Evidence for Heinrich event 1 in the British Isles. Journal of Quaternary Science 13, 549-568.

McCarroll, D., 1991. Ice directions in western Lleyn and the status of the Gwynedd re-advance of the last Irish Sea glacier. Geological Journal 26, 137-143.

McCarroll, D., 1995. Geomorphological evidence from the Llyn Peninsula constraining models of the magnitude and rate of isostatic rebound following deglaciation of the Irish Sea Basin. Geological Journal 30, 157-163.

McCarroll, D., 2001. Deglaciation of the Irish Sea Basin: a critique of the glacimarine model. Journal of Quaternary Science 16, 393-404.

McCarroll, D., 2005. North-west Wales. In Lewis, C.A., Richards, A.E., (eds.) The Glaciations of Wales and Adjacent Areas. Logaston Press 27-40.

McCarroll, D., Harris, C., 1992. The glacigenic deposits of western Lleyn, north Wales: terrestrial or marine? Journal of Quaternary Science 7, 19-29.

McKerrow, W.S., Leggett, J.K., Eales, M.H., 1977. Imbricate thrust model of the Southern Uplands. Nature 267, 237-9.

Merritt, J.W., Auton, C.A., Firth, C.R., 1995. Ice-proximal glaciomarine sedimentation and sea-level change in the Inverness area, Scotland - a review of the deglaciation of a major ice stream of the British late Devensian ice-sheet. Quaternary Science Reviews 14, 289-329.

Merritt, J.W., Auton, C.A., 2000. An outline of the lithostratigraphy and depositional history of Quaternary deposits in the Sellafield district, west Cumbria. Proceedings of the Yorkshire Geological Society 53, 129-154.

Mitchell, G.F., 1960. The Pleistocene history of the Irish Sea. British Association for the Advancement of Science 17, 313-325. 
Mitchell, G.F., 1972. The Pleistocene history of the Irish Sea: a second approximation. Scientific Proceedings of the Royal Dublin Society Series A4, 181199.

Moore, J.C., 1850. Notice of the occurrence of marine shells in the till. Proceedings of the Geological Society of London 6, 388-389.

Ó Cofaigh, C., Evans, D.J.A., 2001. Sedimentary evidence for deforming bed conditions associated with a grounded Irish Sea glacier, Southern Ireland. Journal of Quaternary Science 16, 435-454.

Patterson, C.J., 1997. Southern Laurentide ice lobes were created by ice streams: Des Moines Lobe in Minnesota, USA. Sedimentary Geology 111, 249-261.

Patterson, C.J., 1998. Laurentide glacial landscapes: the role of ice streams. Geology 26, 643-646.

Peacock, J.D., 1975. Scottish late- and post-glacial marine deposits. In Gemmell, A.M.D. (ed.) Quaternary Studies in North East Scotland. Department of Geography, University of Aberdeen 45-48.

Peacock, J.D., Merritt, J.W., 1997. Glacigenic rafting at Castle Hill, Gardenstown, and its significance for the glacial history of northern Banffshire, Scotland. Journal of Quaternary Science 12, 283-294.

Peacock, J.D., Everest, J., (in press). Pre-Late Devensian high Arctic marine deposits in southwest Scotland. Scottish Journal of Geology.

Phillips, E.R., 1989. The Geology of the Monian Supergroup, Western Anglesey, North Wales. Unpublished PhD thesis, University of Wales, Cardiff, pp 470.

Phillips, E.R., 1991a. The lithostratigraphy, sedimentology and tectonic setting of the Monian Supergroup, western Anglesey, North Wales. Journal of the Geological Society of London 148, 1079-1090.

Phillips, E.R., 1991b. Progressive deformation of the South Stack and New Harbour Groups, Holy Island, western Anglesey, North Wales. Journal of the Geological Society of London 148, 1091-1100.

Roberts, D.H., Dackombe, R.V., Thomas, G.S.P., 2007. Palaeo-ice streaming in the central sector of the British-Irish Ice Sheet during the Last Glacial Maximum: evidence from the northern Irish Sea Basin. Boreas 36,115-129.

Salt, K.E., 2001. Palaeo-ice sheet dynamics and depositional settings in south-west Scotland. Unpublished PhD thesis, University of Glasgow.

Salt, K.E., Evans, D.J.A., 2004. Superimposed subglacially streamlined landforms of southwest Scotland. Scottish Geographical Journal 120, 133-147. 
Scourse, J.D., 1991a. Late Pleistocene stratigraphy and palaeobotany of the Isles of Scilly. Philosophical Transactions of the Royal Society of London B334, 405-448.

Scourse, J.D., 1991b. Glacial deposits of the Isles of Scilly. In Ehlers, J., Gibbard, P.L., Rose, J., (eds.) Glacial Deposits in Great Britain and Ireland. A.A. Balkema, Rotterdam 291-300.

Scourse, J.D., Furze, M.F.A., 2001. A critical review of the glaciomarine model for Irish Sea deglaciation: evidence from southern Britain, the Celtic shelf and adjacent continental slope. Journal of Quaternary Science 16, 419-434.

Scourse, J.D., Robinson, E., Evans, C.D.R., 1991. Glaciation of the central and southwestern Celtic Sea. In Ehlers, J., Gibbard, P.L., Rose, J., (eds.) Glacial Deposits in Great Britain. Balkema, Rotterdam 301-310.

Shackleton, R.M., 1969. The Precambrian of North Wales. In Wood, A., (ed.) The Precambrian and Lower Palaeozoic rocks of Wales. University of Wales Press, Cardiff 1-22.

Shackleton, R.M., 1975. Precambrian rocks of Wales. In Harris, A.L., et al., (eds.) A correlation of the Precambrian rocks in the British Isles. Geological Society of London, Special Report 6, 76-82.

Shotton, F.W., Williams, R.E.G., 1973. Birmingham University Radiocarbon Dates VII. Radiocarbon 15, 451-468.

Smith, R.A., Phillips, E.R., Floyd, J.D., Barron, H.F., Pickett, E.A., 2000. The Northern Belt 100 years on: a revised model of the Ordovician tracts near Leadhills, Scotland. Transactions of the Royal Society of Edinburgh: Earth Sciences 91, 421434.

Stokes, C.R., Clark, C.D., 1999. Geomorphological criteria for identifying Pleistocene ice streams. Annals of Glaciology 28, 67-75.

Stokes, C.R., Clark, C.D., 2001. Palaeo-ice streams. Quaternary Science Reviews 20, 1437-1457.

Stokes, C.R., Clark, C.D., Brian O.B., Tulaczyk, S., 2007. Ice stream sticky spots: A review of their identification and influence beneath contemporary and palaeo-ice streams. Earth Science Reviews 81, 217-249.

Stone, P., 1995. Geology of the Rhins of Galloway district. Memoir of the Geological Survey, HMSO, London.

Stone, P., Floyd, J.D., Barnes, R.P., Lintern, B.C., 1987. A sequential back-arc and foreland basin thrust duplex model for the Southern Uplands of Scotland. Journal of the Geological Society of London 144, 753-64.

Strachan, R.A., Collins, A.S., Buchan, C., Nance, R.D., Murphy, J.B., D’Lemos, R. S., 2007. Terrane analysis along a Neoproterozoic active margin of Gondwana: 
insights from $\mathrm{U}-\mathrm{Pb}$ zircon geochronology. Journal of the Geological Society of London 164, 57-60.

Sutherland, D.G., 1993. Port Logan. In Gordon, J.E., \& Sutherland, D.G., (eds.) Quaternary of Scotland, Chapman and Hall, London 593 - 594.

Synge, F.M., 1964. The glacial succession in west Caernarvonshire. Proceedings of the Geologists’ Association 75, 431-444.

Thomas, G.S.P., Chiverrell R.C., 2003. The sand and gravel resources of North West Wales. Report to the Welsh Assembly Government pp 77.

Thomas, G.S.P., Chiverrell, R.C., 2007. Structural and depositional evidence for repeated ice-marginal oscillation along the eastern margin of the Late Devensian Irish Sea Ice Stream. Quaternary Science Reviews 26, 2375-2405.

Thomas, G.S.P., Chester, D.K., Crimes, P., 1988. The late Devensian glaciation of the eastern Llyn peninsula, North Wales: evidence for terrestrial depositional environments. Quaternary Science Reviews 13, 255-270.

Thomas, G.S.P., Chiverrell, R.C., Huddart, D., 2004. Ice-marginal depositional responses to probable Heinrich events in the Devensian deglaciation of the Isle of Man. Quaternary Science Reviews 23, 85-106.

Tiddeman, R.H., 1872. On the evidence for the ice sheet in north Lancashire and adjacent parts of Yorkshire and Westmoreland. Quarterly Journal of the Geological Society 28, 471-489.

Tietzsch-Tyler, D., Phillips, E.R., 1989. Correlation of the Monian Supergroup in NW Anglesey with the Cahore Group in SE Ireland. Journal of the Geological Society of London 146, 417-418.

Van Landeghem, K.J.J., Wheeler, A.J., Mitchell, N.C., 2008. Preserved subglacial and ice-marginal systems offshore Anglesey, UK: reconstructing the final deglaciation conditions of the Irish Sea. Geophysical Research Abstracts 10, EGU2008-A-08190.

Van Landeghem, K.J.J., Wheeler, A.J., Mitchell, N.C., 2009. Seafloor evidence for palaeo-ice streaming and calving of the grounded Irish Sea Ice Stream: Implications for the interpretation of its final deglaciation phase. Boreas 38, 119-131.

Walkden, G., Davies, J.R., 1983. Polyphase erosion of subaerial omission surfaces in the Late Dinantian of Anglesey, north Wales. Sedimentology 30, 861-878.

Williams, G.D., Brabham, P.J., Eaton, G.P., Harris, C., 2001. Late Devensian glaciotectonic deformation at St Bees, Cumbria: a critical wedge model. Journal of the Geological Society of London 158, 125-135. 


\section{Figures}

Fig. 1. (a) Map of the British Isles, showing assumed maximum extent of the Late Devensian British and Irish (BIIS) and southwestern sector of the Fennoscandian (FIS) Ice Sheets. Dashed line indicates disputed limits. Schematic locations are also shown of several of the major ice streams (1-10) which drained the BIIS at different times throughout the Devensian. (b) Map of the northern Irish Sea area showing the principal ice flow directions (large arrows) of the Irish Sea Ice Stream and the location of Anglesey and the Rhins of Galloway close to the eastern margin of this ice stream.

Fig. 2. Frequency plots showing the variation in elongation ratio (elongation ratio = landform length/landform width) of the glacigenic landforms developed within the various assemblage zones recognised on Anglesey (a) assemblage zone 1 north; (b) assemblage zone 1 south; (c) assemblage zone 2 north; (d) assemblage zone 2 south; (e) assemblage zone 3 north; (f) assemblage zone 3 south. Inset - simplified map of the area showing the extent of the main landform assemblage zones.

Fig. 3. (a) Simplified map of Anglesey showing the extent of the main landform assemblage zones. (b) Graph showing the variation in landform elongation ratio (elongation ratio $=$ landform length/landform width), length and width from northeast to southwest across assemblage zone 1. (c) Graph showing the variation in landform elongation ratio, length and width from northeast to southwest across assemblage zone 3. Large arrows denote general trends of increasing or decreasing landform elongation ratio.

Fig. 4. Frequency plots showing the variation in elongation ratio (elongation ratio = landform length/landform width) of the glacigenic landforms developed within the various assemblage zones recognised in the Rhins of Galloway area of southwest Scotland (a) assemblage zone 1; (b) assemblage zone 2; (c) assemblage zone 3. Inset simplified map of the area showing the extent of the main landform assemblage zones.

Fig. 5. (a) Simplified glacigenic landform map of Anglesey, northwest Wales. (b) Simplified geological map of Anglesey showing the distribution of the main lithostratigraphical/tectonostratigraphical units and principle faults (RA - Rhoscolyn Anticline).

Fig. 6. NEXTMap digital elevation model of Anglesey showing: (a) the distribution of the three main landform assemblage zones (after Thomas and Chiverrell, 2007); and (b) the distribution of the three major landform assemblage zones, long axis orientation of drumlins and other streamlined subglacial landforms, and the main pattern of ice flow across the island overlain upon a colour graduated raster image showing the variation in landform elongation ratio across the study area.

Fig. 7. Detailed NEXTMap digital elevation model images showing: (a) the variation in drumlin morphology across the Carmel Head Thrust. The area immediately to the north of the thrust is devoid of constructional landforms and marked by a bedrock high; (b) the rectilinear pattern formed by the landforms developed in the Llyn Traffwll to Trefor area; and (c) the Treath Dulas and Mynydd Bodafon area. Note the bedrock high developed over the area of outcrop of the Carboniferous (Dinantian) 
limestone dominated sequence and the deflection in the pattern of ice flow around the western margin of this high.

Fig. 8. NEXTMap image of northern Anglesey showing the variation in the geometry and distribution of constructional subglacial landforms across the Carmel Head Thrust. The 1:50,000 digital bedrock geology map has been draped over the digital terrane model so as to highlight the relationship between the variation in landform morphology and bedrock geology.

Fig. 9. (a) Contoured lower hemisphere stereographic projection of the dip and dip azimuth data for the S1 foliation within the New Harbour Group and poles to this planar foliation ( $\mathrm{N}=125)$; (b) Contoured lower hemisphere stereographic projection of the plunge and orientation of minor folds deforming S1 foliation within the New Harbour Group ( $\mathrm{N}=177)$; (c) Rose diagram showing the orientation of the long axes of drumlins within assemblage subzone $1 \mathrm{~b}(\mathrm{~N}=67)$, range in strike of the $\mathrm{S} 1$ foliation and mean orientation of the minor folds developed within the New Harbour Group; and (d) Lower hemisphere stereographic projection showing the dip and strike of bedding (pale grey; $\mathrm{N}=4$ ) and cleavage (dark grey; $\mathrm{N}=5$ ) within the Ordovician strata exposed near Llyn Traffwll, and mean orientation of the linear features defining the rectilinear pattern of landform assemblage subzone 1e (see Fig. 4 for location of landform assemblage zones).

Fig. 10. (a) Simplified glacigenic landform map of the Rhins of Galloway, southwest Scotland. (b) Simplified geological map of the Rhins of Galloway showing the distribution of the main lithostratigraphical/tectonostratigraphical units and principle faults.

Fig. 11. NEXTMap digital elevation model of the Rhins of Galloway showing: (a) the distribution of the three main landform assemblage zones; and (b) the distribution of the three major landform assemblage zones, long axis orientation of drumlins and other streamlined subglacial landforms, and the main pattern of ice flow across the this part of southwest Scotland overlain upon a colour graduated raster image showing the variation in landform elongation ratio across the area.

Fig. 12. Detailed NEXTMap digital elevation model images showing: (a) the variation in the orientation of the landforms across bedrock faults; and (b) the northern end of the Rhins of Galloway.

Fig. 13. (a) Lower hemisphere stereographic projection of the poles to bedding within the Lower Palaeozoic rocks of the Rhins of Galloway ( $\mathrm{N}=196$; data from Stone 1995); and (b) Rose diagram showing the orientation of the long axes of drumlins within assemblage zones $1(\mathrm{~N}=67)$ and $2(\mathrm{~N}=68)$, range in strike of bedding within the Lower Palaeozoic rocks of the Rhins of Galloway (see Fig. 9 for location of landform assemblage zones).

Fig. 14. 3D block diagram showing the proposed concentration of relatively faster moving ice above the less durable Carboniferous (Pennsylvanian) coal-bearing sedimentary rocks in western-central Anglesey. Erosion and over deepening by the ice in the area of these softer rocks resulted in the formation of a linear trough, constrained to the west by the fault scarp formed by the Berw Fault. Lines 1 to 5 
correspond to the westerly expansion of the relatively faster ice across central Anglesey.

Tables

Table 1. Statistical data for landform elongation ratio (elongation ratio = landform length/landform width), length and width from Anglesey, northwest Wales.

\begin{tabular}{|c|c|c|c|c|c|c|}
\hline & \multicolumn{3}{|c|}{ Assemblage Zone 1 (north) } & \multicolumn{3}{|c|}{ Assemblage Zone 1 (south) } \\
\hline & $\begin{array}{c}\text { elongation } \\
\text { ratio }\end{array}$ & length $(\mathrm{km})$ & width $(\mathrm{km})$ & $\begin{array}{c}\text { elongation } \\
\text { ratio }\end{array}$ & length $(\mathrm{km})$ & width $(\mathrm{km})$ \\
\hline Mean & 2.02 & 0.69 & 0.37 & 2.41 & 0.78 & 0.35 \\
\hline $\begin{array}{l}\text { Standard } \\
\text { Deviation }\end{array}$ & 0.68 & 0.23 & 0.15 & 1.00 & 0.27 & 0.15 \\
\hline Minimum & 0.91 & 0.29 & 0.12 & 0.78 & 0.31 & 0.12 \\
\hline Maximum & 4.62 & 1.52 & 0.77 & 9.26 & 1.94 & 0.97 \\
\hline \multirow[t]{3}{*}{ Count } & 83 & 83 & 83 & 360 & 360 & 360 \\
\hline & \multicolumn{3}{|c|}{ Assemblage Zone 2 (north) } & \multicolumn{3}{|c|}{ Assemblage Zone 2 (south) } \\
\hline & $\begin{array}{c}\text { elongation } \\
\text { ratio }\end{array}$ & length $(\mathrm{km})$ & width $(\mathrm{km})$ & $\begin{array}{c}\text { elongation } \\
\text { ratio }\end{array}$ & length $(\mathrm{km})$ & width $(\mathrm{km})$ \\
\hline Mean & 4.31 & 1.03 & 0.25 & 3.99 & 1.07 & 0.28 \\
\hline $\begin{array}{l}\text { Standard } \\
\text { Deviation }\end{array}$ & 1.79 & 0.57 & 0.12 & 1.58 & 0.48 & 0.11 \\
\hline Minimum & 1.70 & 0.26 & 0.07 & 1.77 & 0.41 & 0.10 \\
\hline Maximum & 10.84 & 3.52 & 0.69 & 10.67 & 2.81 & 0.68 \\
\hline \multirow[t]{3}{*}{ Count } & 75 & 75 & 75 & 88 & 88 & 88 \\
\hline & \multicolumn{3}{|c|}{ Assemblage Zone 3 (north) } & \multicolumn{3}{|c|}{ Assemblage Zone 3 (south) } \\
\hline & $\begin{array}{l}\text { elongation } \\
\text { ratio }\end{array}$ & length $(\mathrm{km})$ & width $(\mathrm{km})$ & $\begin{array}{l}\text { elongation } \\
\text { ratio }\end{array}$ & length $(\mathrm{km})$ & width $(\mathrm{km})$ \\
\hline Mean & 3.59 & 0.88 & 0.27 & 3.48 & 1.41 & 0.42 \\
\hline $\begin{array}{l}\text { Standard } \\
\text { Deviation }\end{array}$ & 1.67 & 0.29 & 0.10 & 1.23 & 0.84 & 0.22 \\
\hline Minimum & 1.52 & 0.26 & 0.11 & 1.92 & 0.53 & 0.16 \\
\hline Maximum & 11.51 & 1.94 & 0.58 & 7.05 & 4.41 & 0.97 \\
\hline Count & 75 & 75 & 75 & 33 & 33 & 33 \\
\hline
\end{tabular}


Table 2. Statistical data for landform elongation ratio (elongation ratio = landform length/landform width), length and width from the Rhins of Galloway, southwest Scotland.

\begin{tabular}{|c|c|c|c|}
\hline & \multicolumn{3}{|c|}{ Assemblage Zone 1} \\
\hline & $\begin{array}{l}\text { elongation } \\
\text { ratio }\end{array}$ & length $(\mathrm{km})$ & width $(\mathrm{km})$ \\
\hline Mean & 2.49 & 0.54 & 0.23 \\
\hline $\begin{array}{l}\text { Standard } \\
\text { Deviation }\end{array}$ & 0.76 & 0.17 & 0.08 \\
\hline Minimum & 1.09 & 0.23 & 0.09 \\
\hline Maximum & 5.98 & 1.50 & 0.65 \\
\hline \multirow[t]{3}{*}{ Count } & 354 & 354 & 354 \\
\hline & \multicolumn{3}{|c|}{ Assemblage Zone 2} \\
\hline & $\begin{array}{l}\text { elongation } \\
\text { ratio }\end{array}$ & length $(\mathrm{km})$ & width $(\mathrm{km})$ \\
\hline Mean & 3.89 & 0.84 & 0.22 \\
\hline $\begin{array}{l}\text { Standard } \\
\text { Deviation }\end{array}$ & 1.83 & 0.47 & 0.09 \\
\hline Minimum & 1.47 & 0.29 & 0.07 \\
\hline Maximum & 10.61 & 2.54 & 0.55 \\
\hline \multirow[t]{3}{*}{ Count } & 78 & 78 & 78 \\
\hline & \multicolumn{3}{|c|}{ Assemblage Zone 3} \\
\hline & $\begin{array}{l}\text { elongation } \\
\text { ratio }\end{array}$ & length $(\mathrm{km})$ & width $(\mathrm{km})$ \\
\hline Mean & 3.31 & 0.52 & 0.16 \\
\hline $\begin{array}{l}\text { Standard } \\
\text { Deviation }\end{array}$ & 1.31 & 0.19 & 0.05 \\
\hline Minimum & 1.19 & 0.19 & 0.05 \\
\hline Maximum & 8.76 & 1.55 & 0.50 \\
\hline Count & 517 & 517 & 517 \\
\hline
\end{tabular}




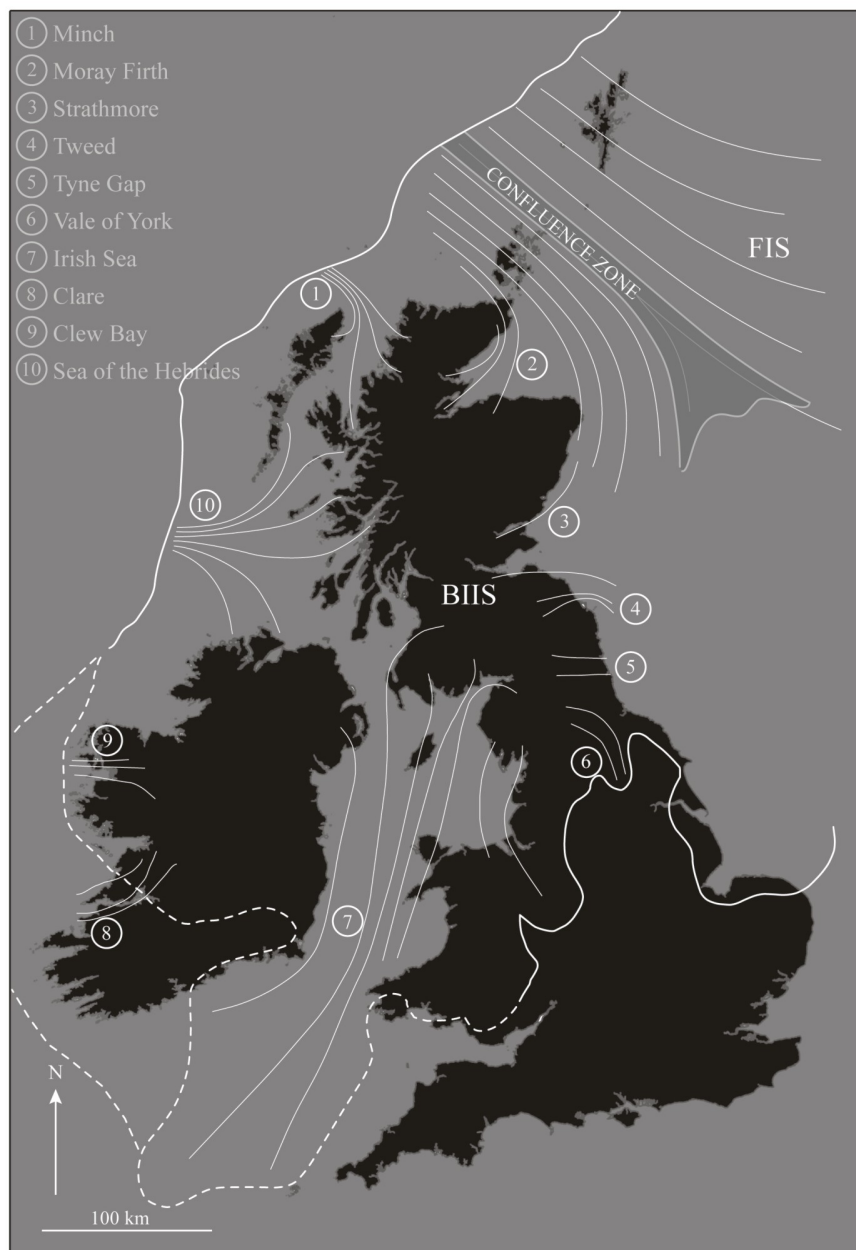

(a)

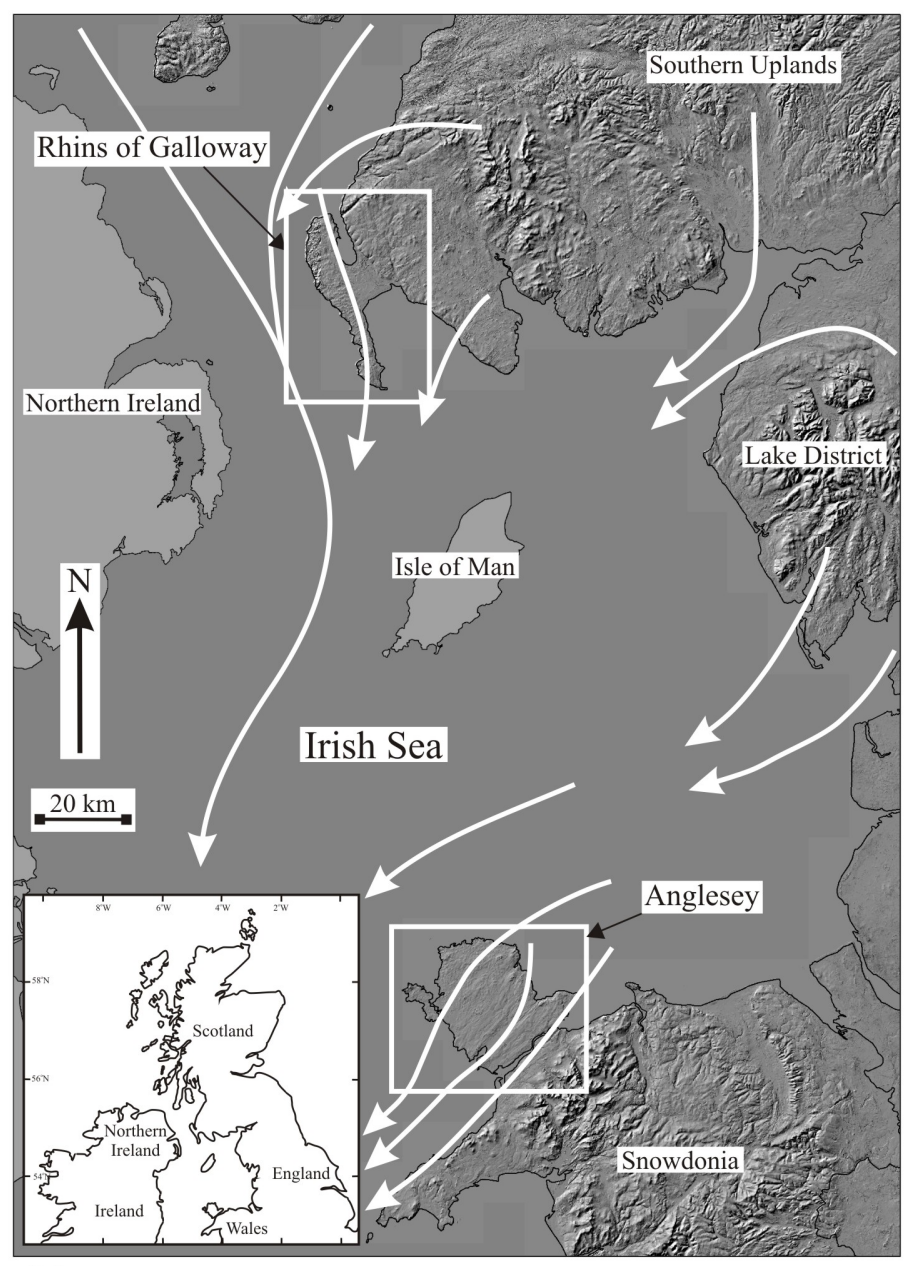

(b)

Fig. 1. (a) Map of the British Isles, showing assumed maximum extent of the Late Devensian British and Irish (BIIS) and SW-sector of the Fennoscandian (FIS) Ice Sheets. Dashed line indicates disputed limits. Schematic locations are also shown of several of the major ice streams (1-10) which drained the BIIS at different times throughout the Devensian. (b) Map of the northern Irish Sea area showing the principal ice flow directions (large arrows) of the Irish Sea Ice Stream and the location of Anglesey and the Rhins of Galloway close to the eastern margin of this ice stream. 


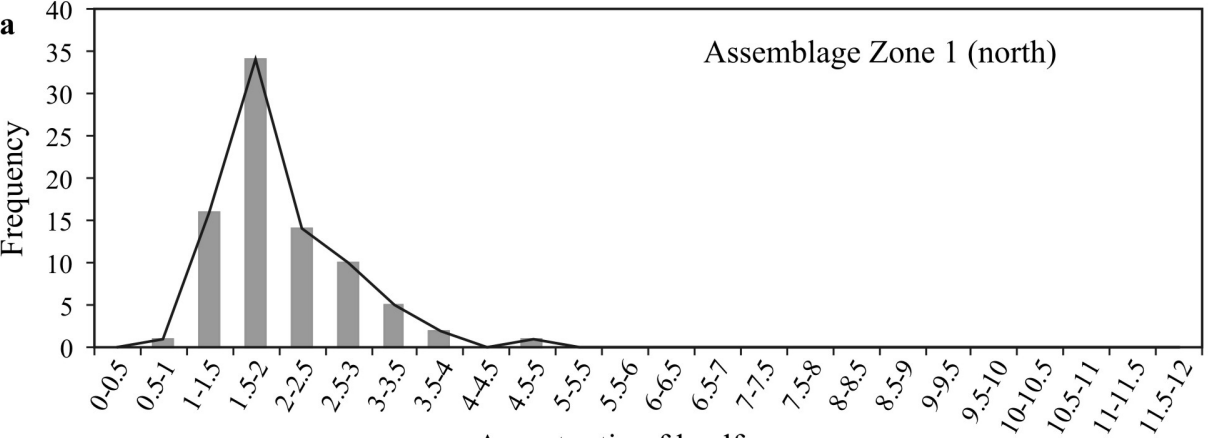

Aspect ratio of landforms

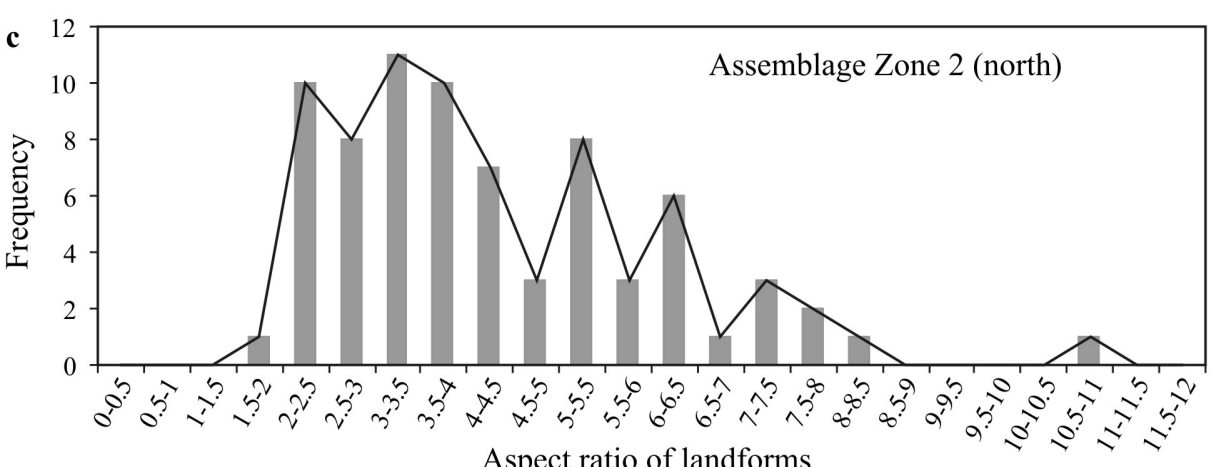

Aspect ratio of landforms

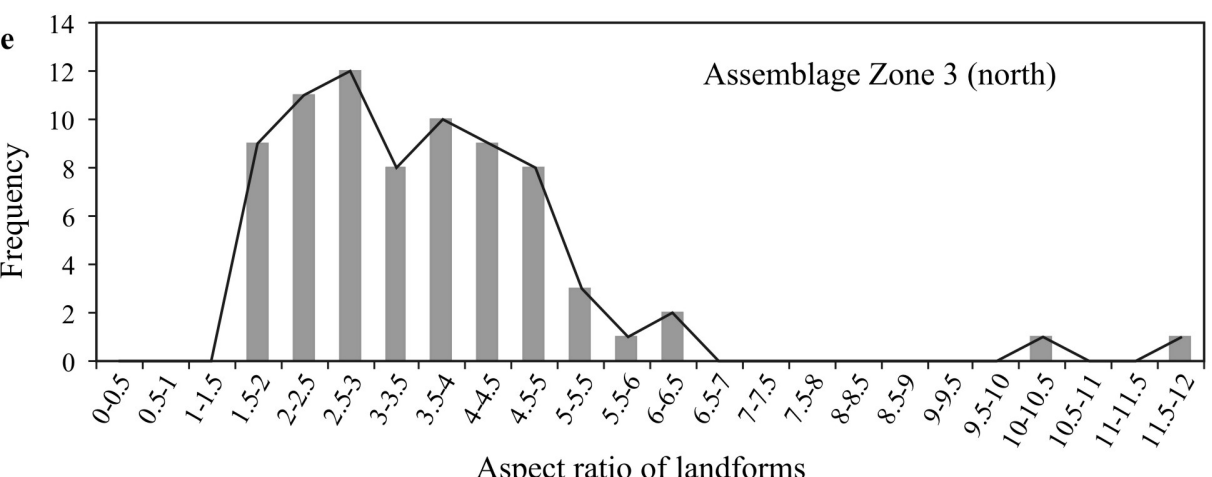

Aspect ratio of landforms

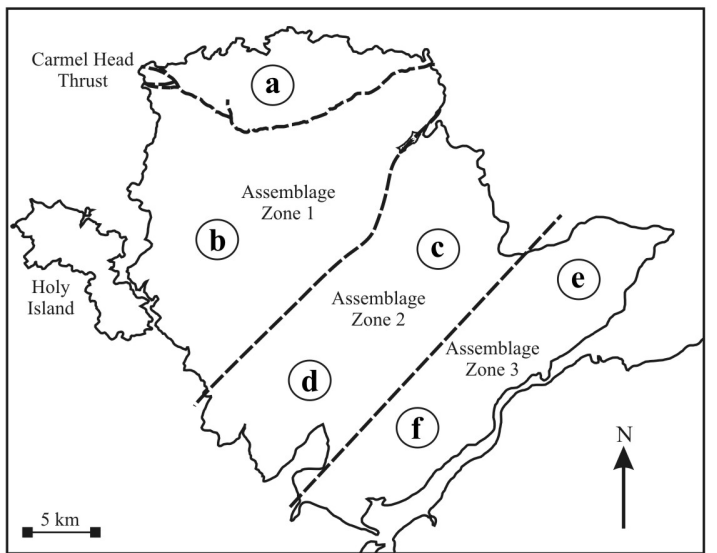

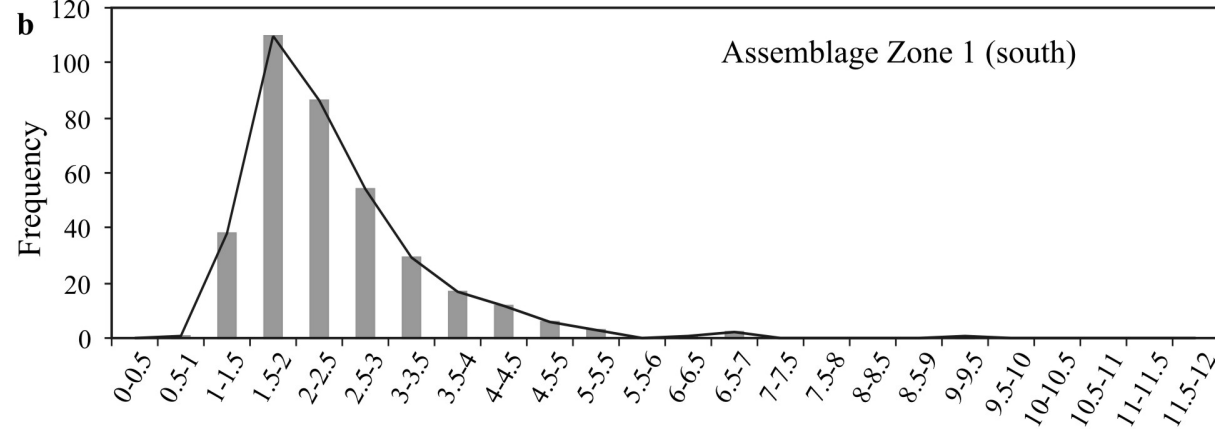

Aspect ratio of landforms

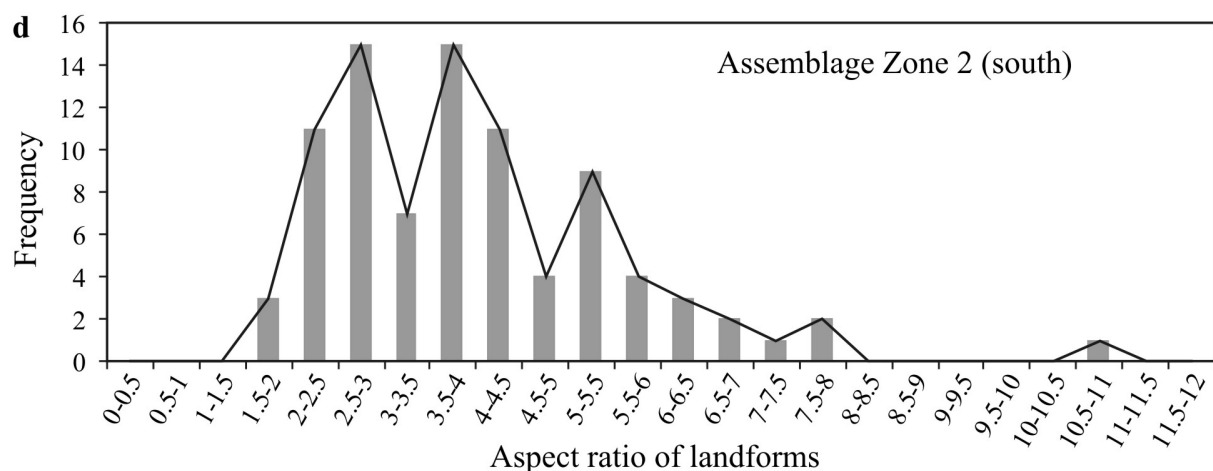

Aspect ratio of landforms

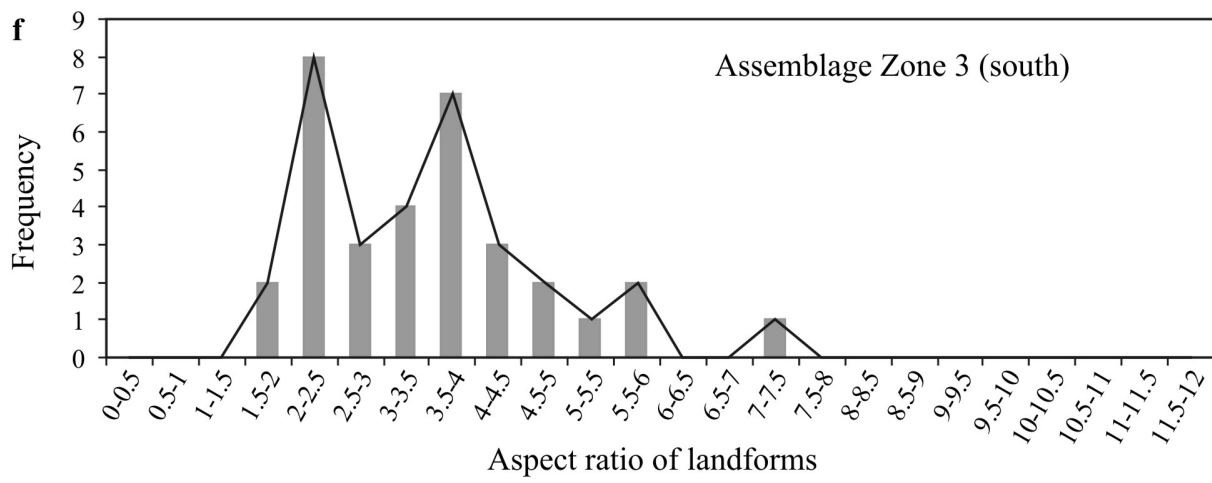

Fig. 2. Frequency plots showing the variation in aspect ratio of the glacigenic landforms developed within the various assemblage zones recognised on Anglesey (a) assemblage zone 1 north; (b) assemblage zone 1 south; (c) assemblage zone 2 north; (d) assemblage zone 2 south; (e) assemblage zone 3 north; (f) assemblage zone 3 south. Inset - simplified map of the area showing the extent of the main landform assemblage zones. 

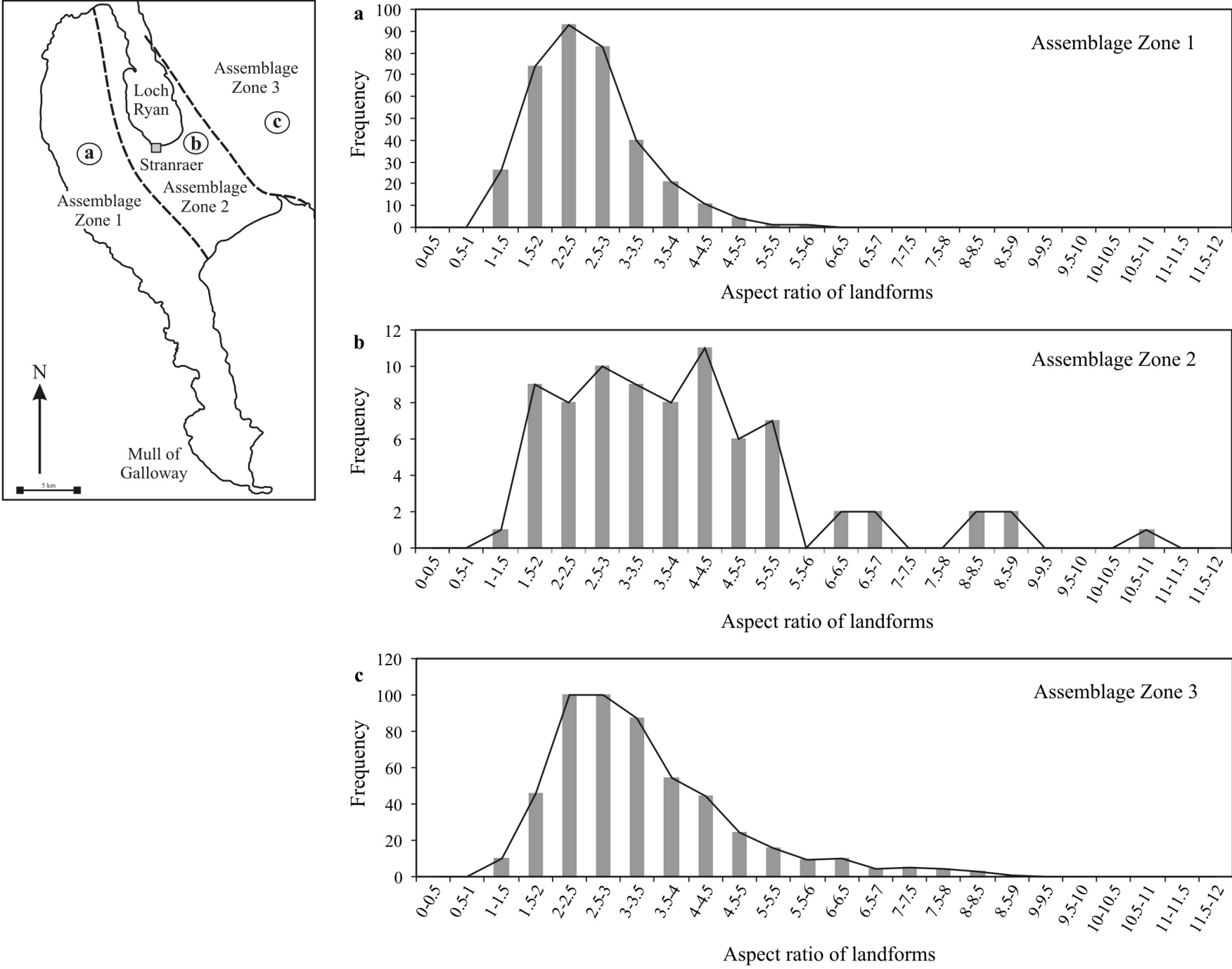

Fig. 4. Frequency plots showing the variation in aspect ratio of the glacigenic landforms developed within the various assemblage zones recognised in the Rhins of Galloway area of SW Scotland (a) assemblage zone 1; (b) assemblage zone 2; (c) assemblage zone 3. Inset - simplified map of the area showing the extent of the main landform assemblage zones. 


\section{(a) Carmel Head Thrust}

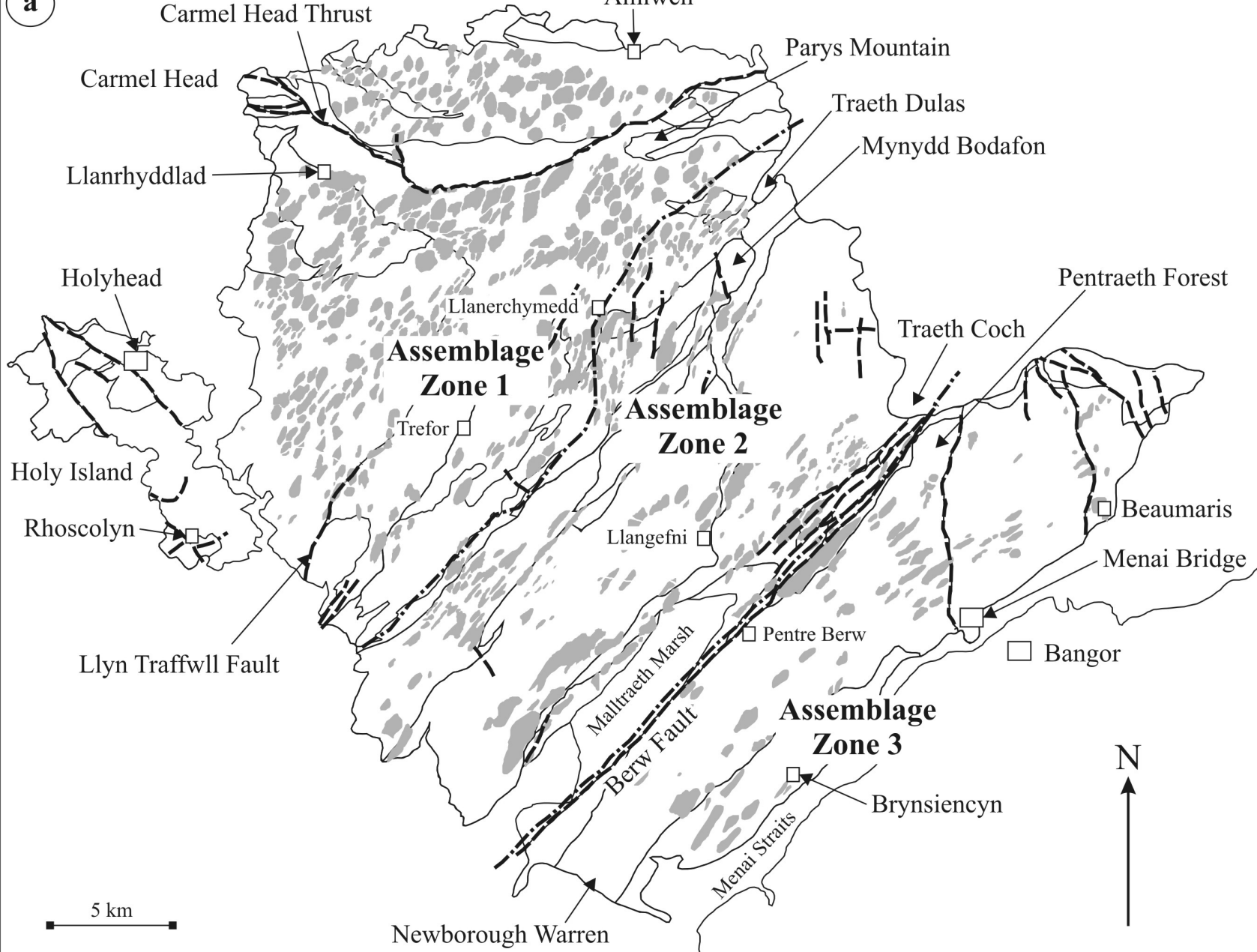

Newborough Warren

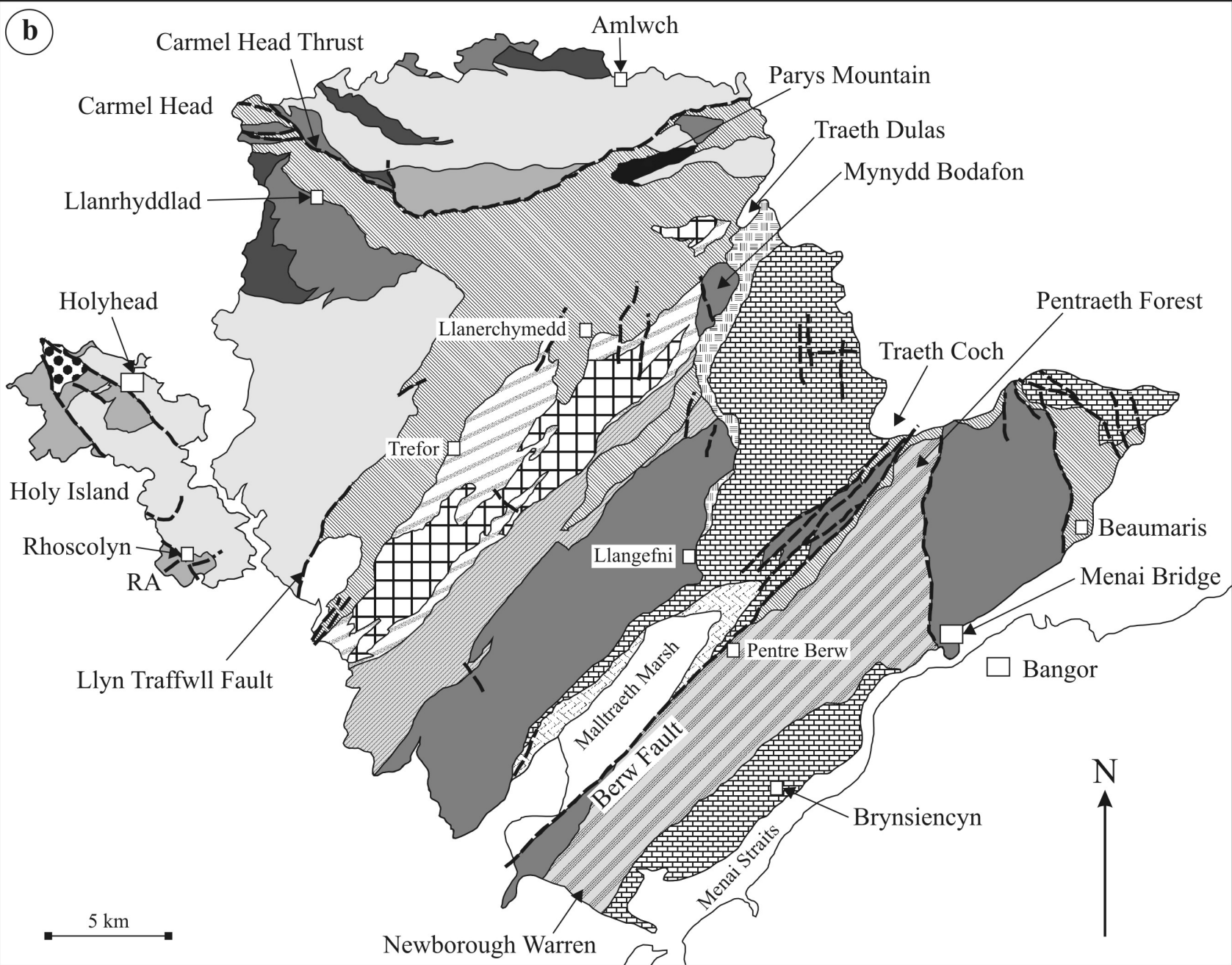

\section{Mona Complex}

Gwna Group - regional-scale olistostromic mélange

Skerries Formation (New Harbour Group) - volcaniclastic metasandstones

New Harbour Group - schistose metamudstones and metasandstones

8.8 Holy Island Group (Cambrian) - Holyhead Quartzite

Holy Island Group (Cambrian) - turbiditic metasandstones and metamudstones

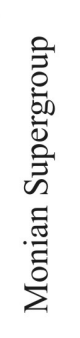

'Blueschist terrane' - schistose Neoproterozoic metasedimentary and meta-igneous rocks

Central Anglesey Shear Zone - schistose metasedimentary and meta-igneous rocks

\section{Coedana Granite}

Neoproterozoic metasedimentary and metamafic gneisses
Carboniferous (Pennsylvanian) - coal-bearing succession

監 Carboniferous (Dinantian) - shallow marine carbonate succession

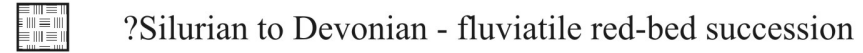

Silurian - deep marine mudstones and volcanic rocks

$\mathbb{N}$ Ordovician - sandstone and conglomerate dominated sequence

- - faults

bedrock geological boundaries

landforms

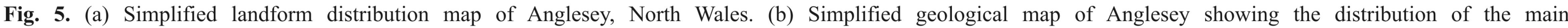
lithostratigraphical/tectonostratigraphical units and principle faults (RA-Rhoscolyn Anticline). 


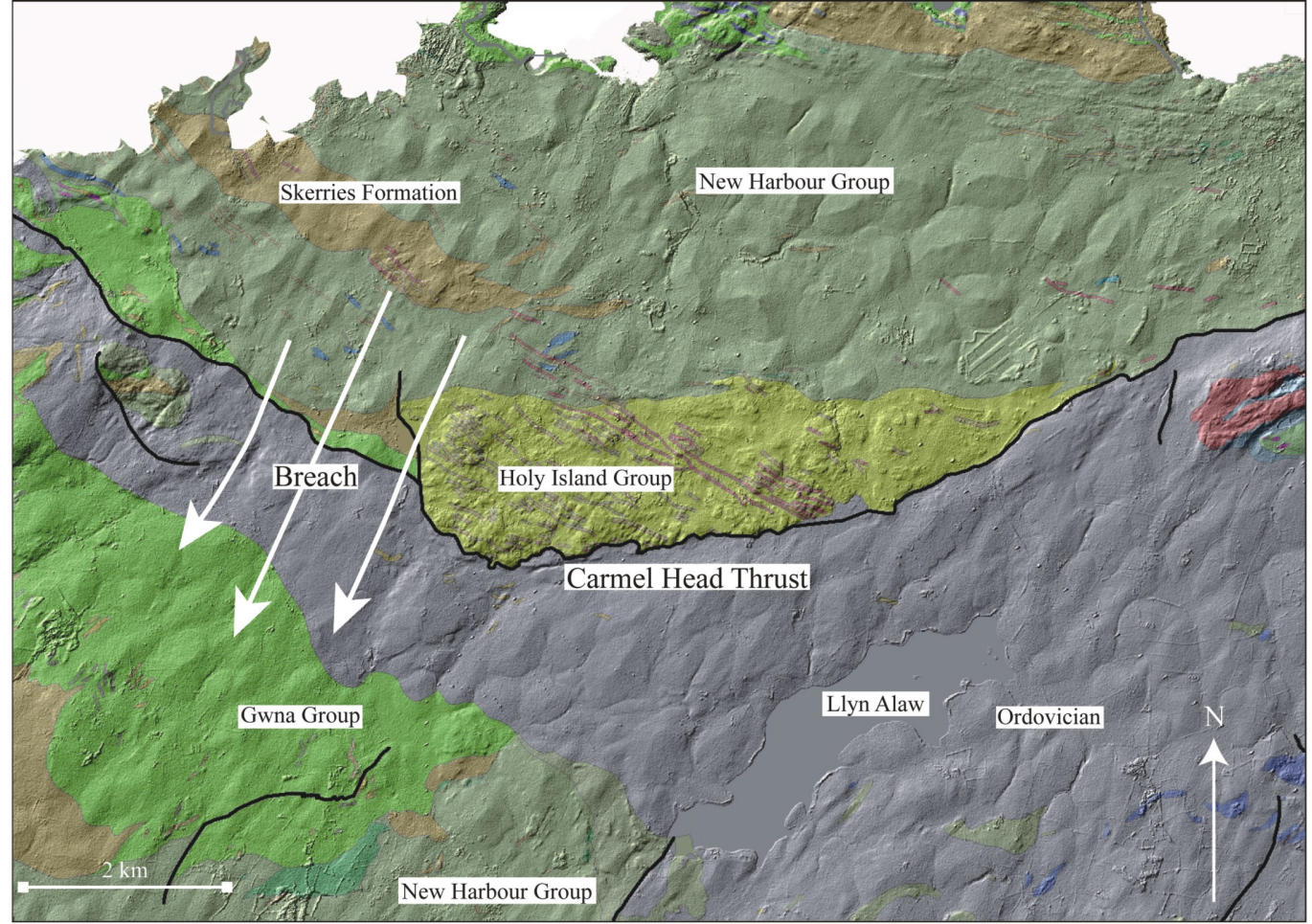

Fig. 8. NEXTMap image of northern Anglesey showing the variation in the geometry and distribution of constructional subglacial landforms across the Carmel Head Thrust. The 1:50,000 digital bedrock geology map has been draped over the digital terrane model so as to highlight the relationship between the variation in landform morphology and bedrock geology. 

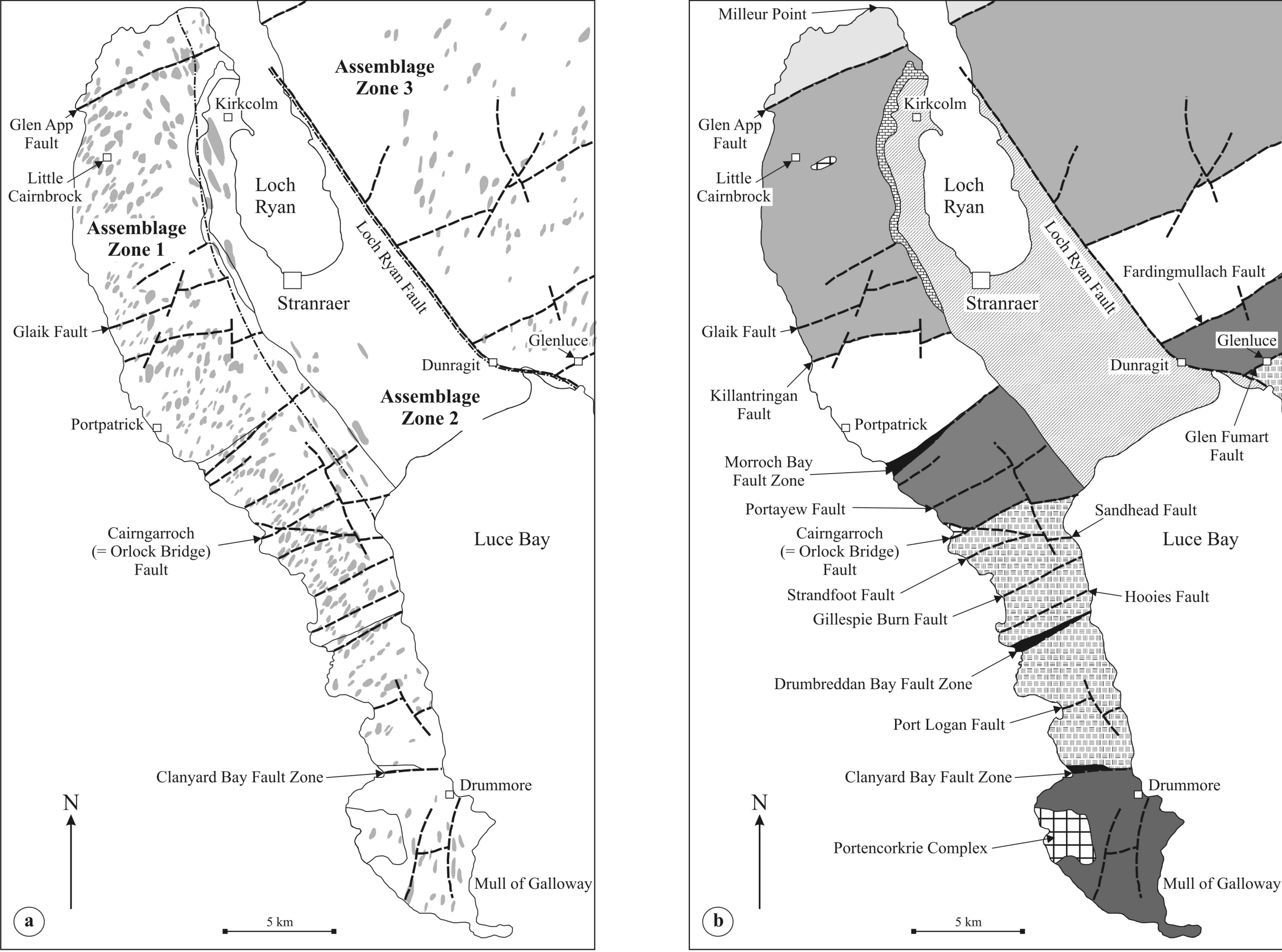

Permian

覽 Carboniferous

四 granitic intrusions

Moffat Shale Group

Hawick Group (Silurian)

Gala Group (Silurian)
Shinnel Formation (Ordovician), Leadhills Supergroup

Portpatrick Formation (Ordovician), Leadhills Supergroup

Kirkcolm Formation (Ordovician), Leadhills Supergroup

Corsewall Formation (Ordovician), Leadhills Supergroup

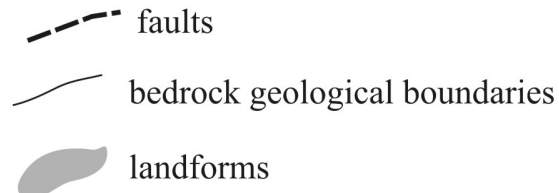

- - faults

landforms

Fig. 10. (a) Simplified landform distribution map of the Rhins of Galloway, SW Scotland. (b) Simplified geological map of the Rhins of Galloway showing the distribution of the main lithostratigraphical/tectonostratigraphical units and principle faults. 


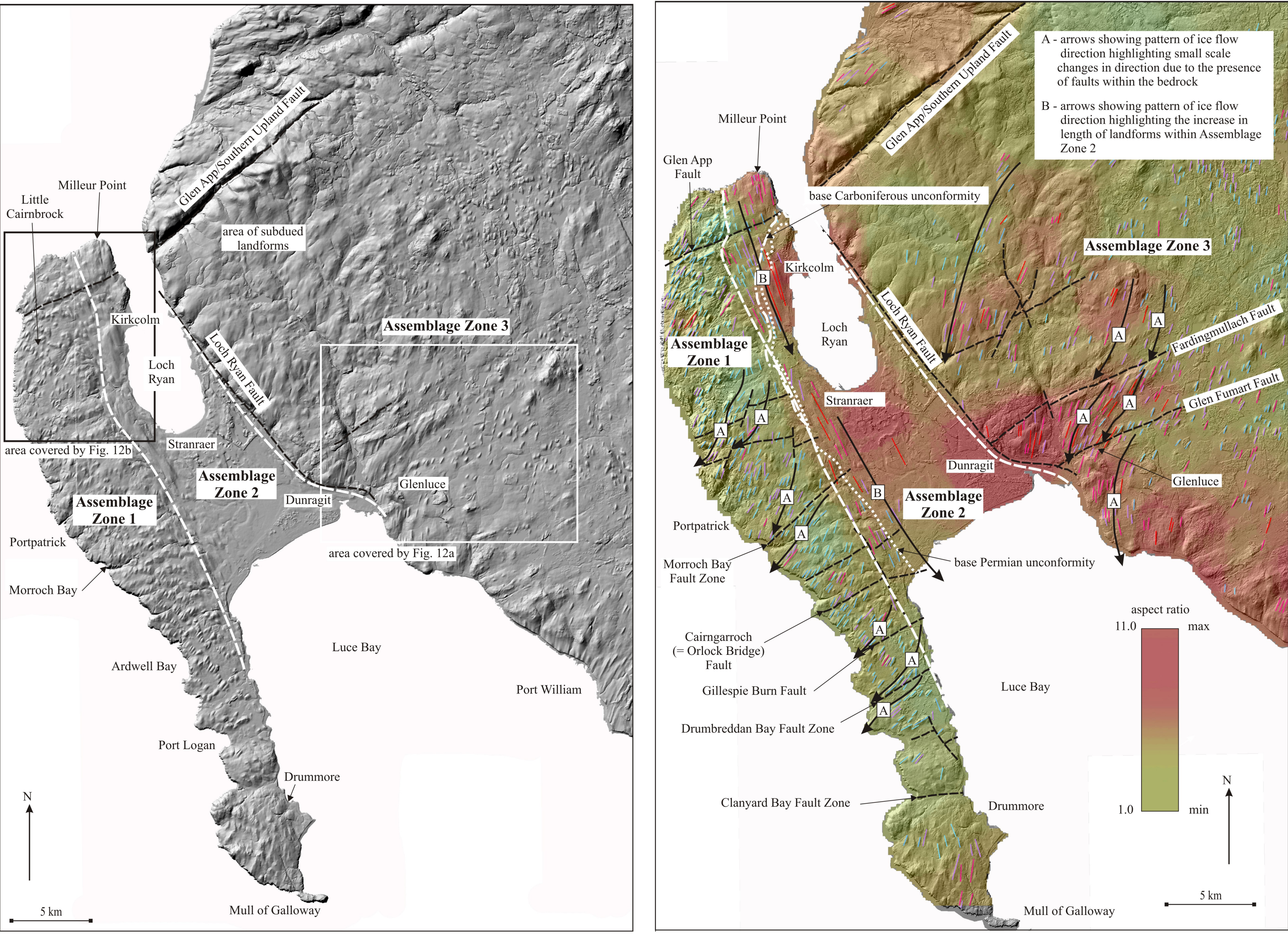

Fig. 11. NEXTMap digital terrane model of Rhins of Galloway, southwest Scotland, showing the distribution of the three main landform assemblage zones. Insets: (a) Detailed image showing the variation in the orientation of the landforms across bedrock faults; and (b) Detailed image of the northern end of the Rhins of Galloway. 

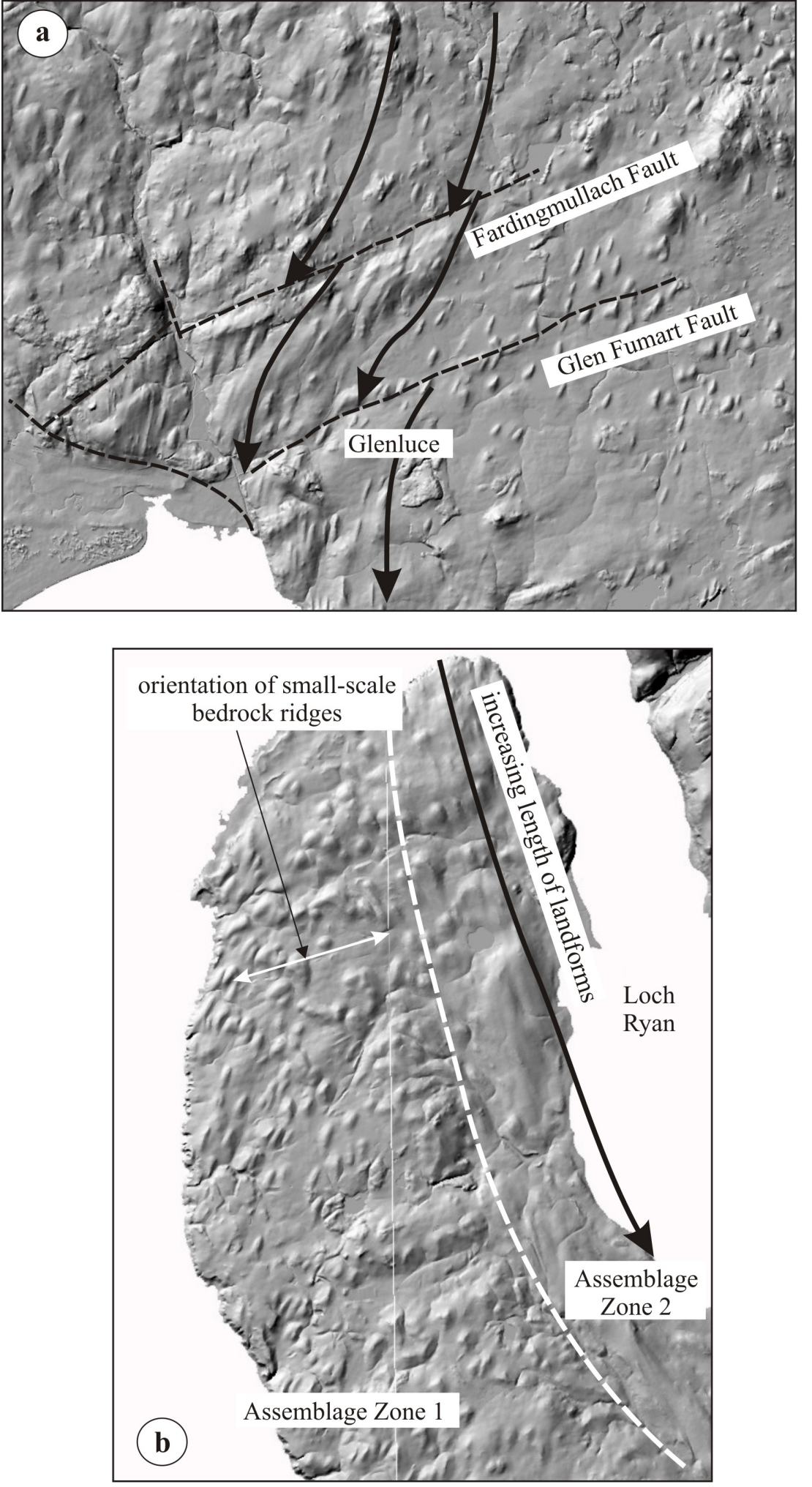

Fig. 12. Detailed NEXTMap digital terrain model images showing: (a) the variation in the orientation of the landforms across bedrock faults; and (b) the northern end of the Rhins of Galloway. 


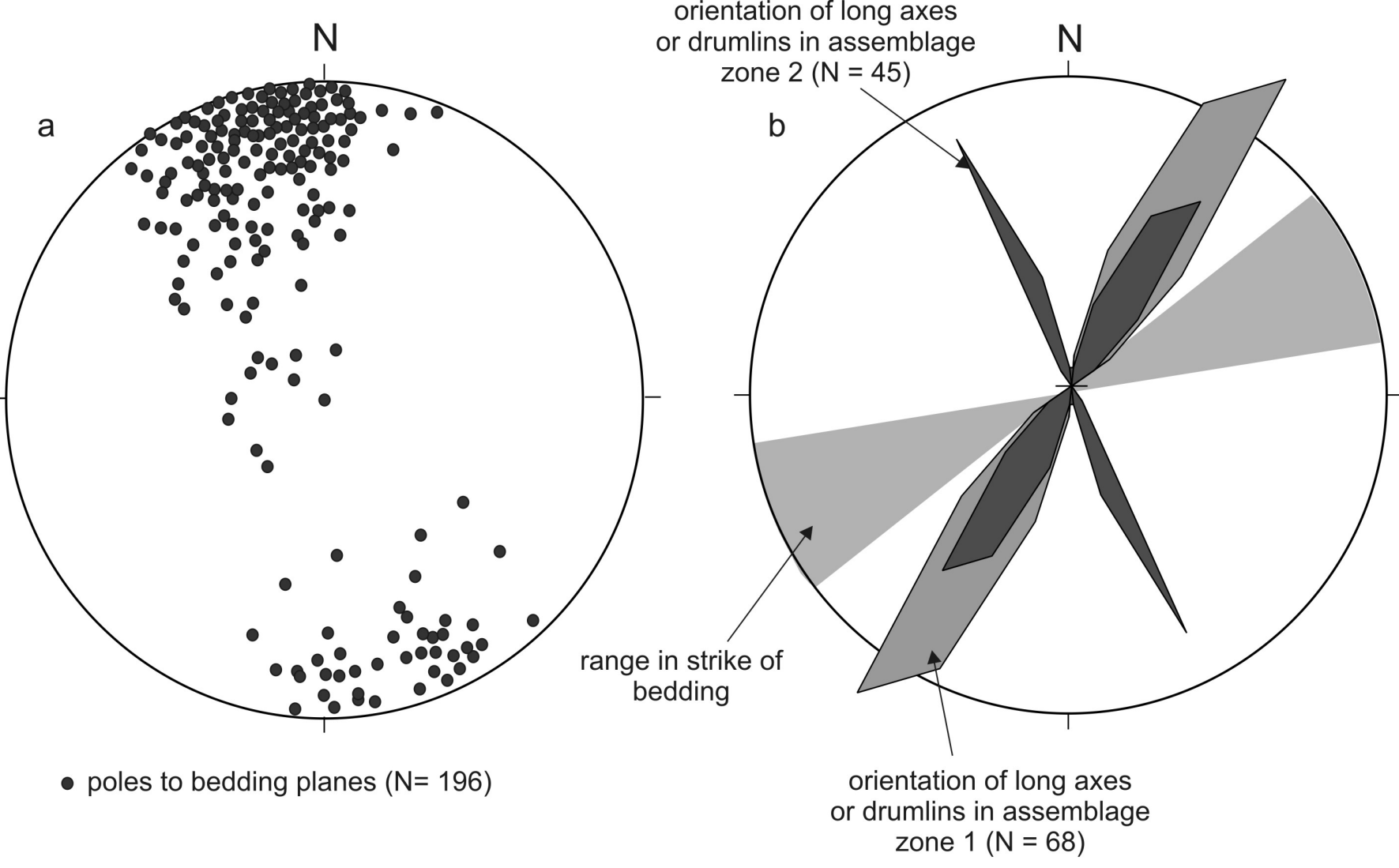

Fig. 13. (a) Lower hemisphere stereographic projection of the poles to bedding within the Lower Palaeozoic rocks of the Rhins of Galloway ( $\mathrm{N}=196$; data from Stone 1995); and (b) Rose diagram showing the orientation of the long axes of drumlins within assemblage zones $1(\mathrm{~N}=67)$ and $2(\mathrm{~N}=68)$, range in strike of bedding within the Lower Palaeozoic rocks of the Rhins of Galloway (see Fig. 11 for location of landform assemblage zones). 


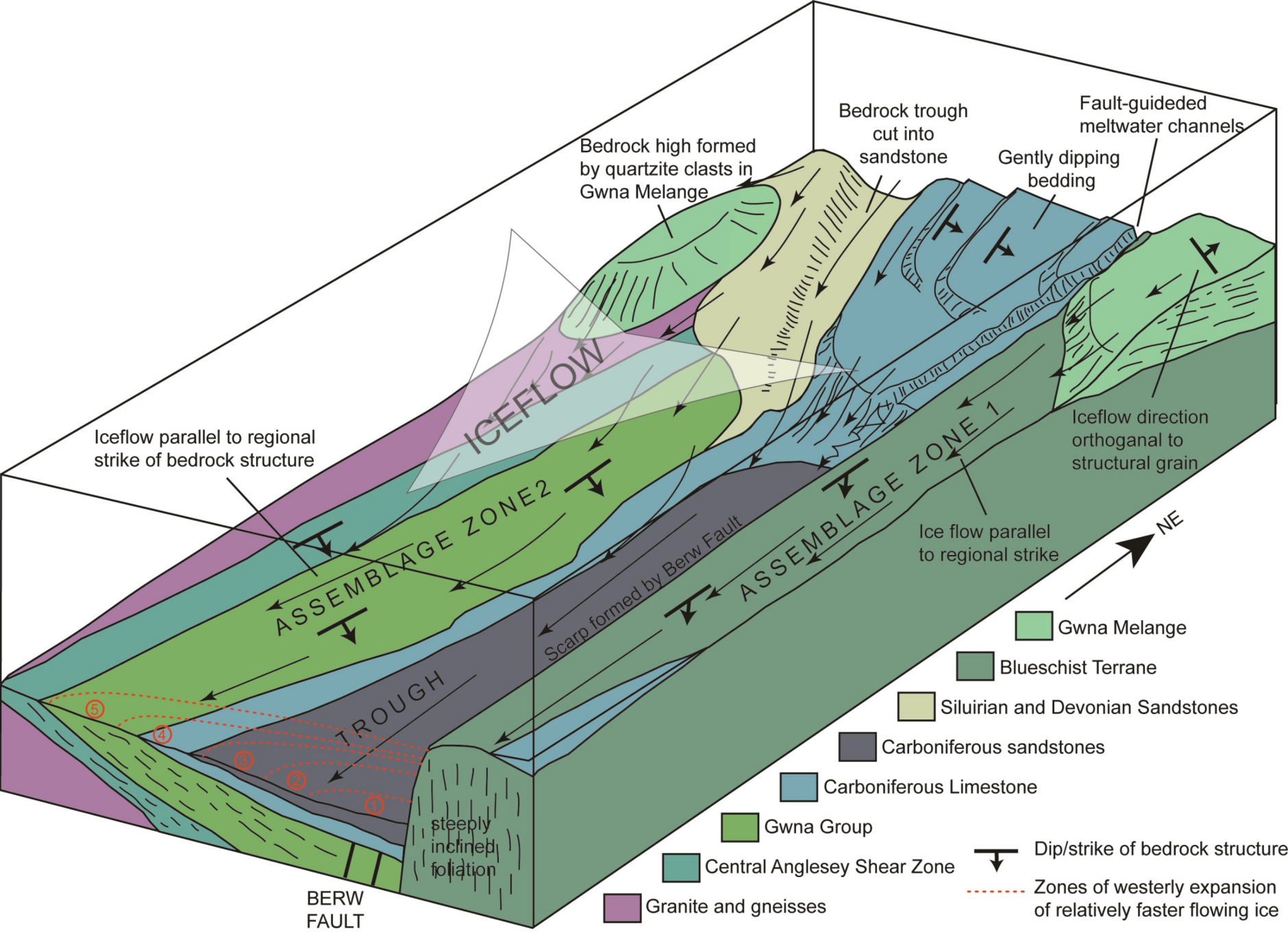

Fig. 14. 3D block diagram showing the proposed concentration of relatively faster moving ice above the less durable Carboniferous (Pennsylvanian) coal-bearing sedimentary rocks in western-central Anglesey. Erosion and over deepening by the ice in the area of these softer rocks resulted in the formation of a linear trough, constrained to the west by the fault scarp formed by the Berw Fault. Lines 1 to 5 correspond to the westerly expansion of the relatively faster ice across central Anglesey. 